\title{
Delivery of drugs, proteins and genes into cells using transferrin as a ligand for receptor-mediated endocytosis
}

\author{
Ernst Wagner ${ }^{\mathrm{a},{ }^{*}}$, David Curiel ${ }^{\mathrm{b}}$, Matt Cotten ${ }^{\mathrm{a}}$ \\ ${ }^{a}$ Research Institute of Molecular Pathology, Dr. Bohr-Gasse 7, A-1030 Vienna, Austria \\ ${ }^{b}$ Gene Therapy Program, University of Alabama, Birmingham, AL, USA
}

(Received February 23,1993; Accepted July 1, 1993)

\section{Contents}

Abstract 114

1. Introduction 114

2. Physiology of transferrin and transferrin receptor. 114

2.1. Transferrin (Tf) and transferrin receptor (TfR) 114

2.2. Receptor-mediated endocytosis and the intracellular cycle. 115

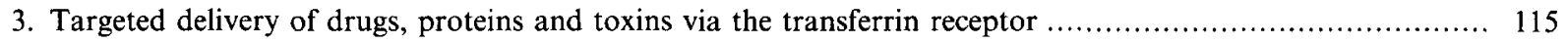

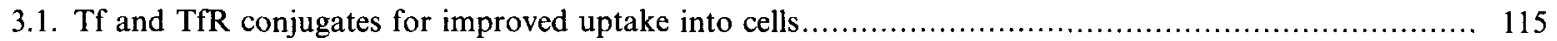

3.2. Targeting to various cell types via the transferrin receptor ............................................ 119

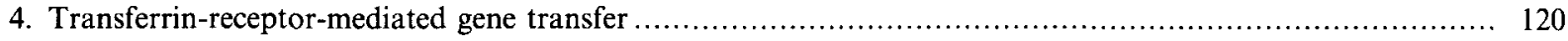

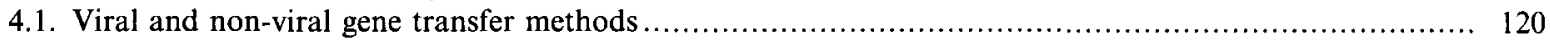

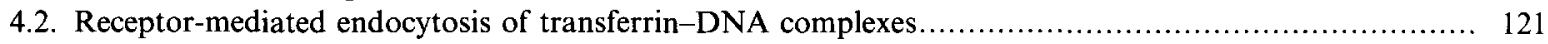

4.3. Intracellular fate and expression of gene constructs in various cell types ................................ 122

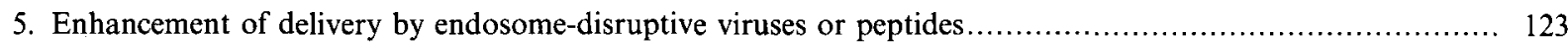

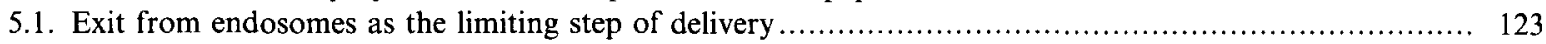

5.2. Viral particles promote exit from endosomes ............................................................. 123

5.3. Enhancement of gene transfer by membrane-disruptive peptides ............................................. 126

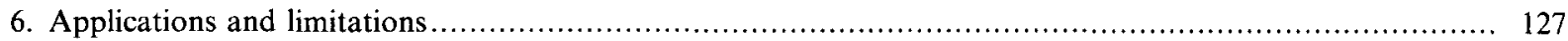

\footnotetext{
${ }^{*}$ Corresponding author.
}

Abbreviations: $\mathrm{Tf}=$ transferrin; $\mathrm{TfR}=$ transferrin receptor; $\alpha \mathrm{TfR}=$ anti-transferrin receptor antibody; $\mathrm{AdV}=$ adenovirus; $\mathrm{DT}=$ diphtheria toxin; $\mathrm{PE}=$ Pseudomonas exotoxin 
6.1. Gene delivery ex vivo and in vivo.....

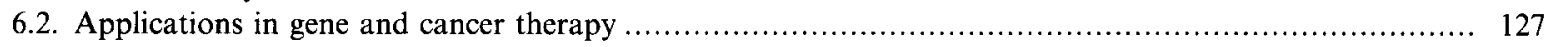

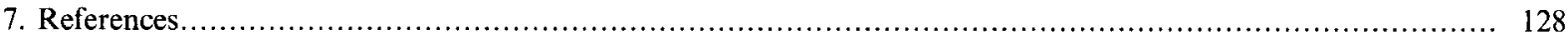

\begin{abstract}
Transferrin, an iron-transporting serum glycoprotein, is efficiently taken up into cells by the process of receptormediated endocytosis. Transferrin receptors are found on the surface of most proliferating cells, in elevated numbers on erythroblasts and on many kinds of tumors. The efficient cellular mechanism for uptake of transferrin has been subverted for the delivery of low-molecular-weight drugs, protein toxins, and liposomes by linkage of these agents to transferrin or to anti-transferrin receptor antibodies. Linkage may be via chemical conjugation procedures or by the generation of chimeric fusion proteins. Transferrin conjugated to DNA-binding compounds (e.g. polycations or intercalating agents) has been successfully used for the import of DNA molecules into cells. High-level gene expression is obtained only if endosome-disruptive agents such as influenza hemagglutinin peptides or adenovirus particles are included which release the DNA complex from intracellular vesicles into the cytoplasm.
\end{abstract}

Key words: Adenovirus; DNA transfection; Drug delivery; Endocytosis; Endosome disruption; Gene transfer; Gene therapy; Immunotoxin; Polylysine; Transferrin

\section{Introduction}

The high efficacy of the transferrin endocytosis process has tempted many investigators to ask whether this pathway could be exploited for the targeted delivery of drugs or larger molecules into cells. The first part of this article reviews the delivery of drugs and toxin proteins. A series of successful application in vitro and in vivo have been described. The use of toxin proteins appears particularly advantageous because the successful delivery of one to two toxin molecules to the cytoplasm may kill a cell, thereby providing a most sensitive test system which is essential for further improvement of the delivery systems. Recent advances in molecular biology have also supplied sensitive detection methods to assess gene transfer techniques. The major part of this review discusses the use of the transferrin uptake pathway for the delivery of genes into cells. This concept may broaden the range of applications, as genes may be designed to have either a cytotoxic or a biologically curative effect on cells, and the gene products may be produced in numerous copies over an extended period. The first section describing the natural role of transferrin has been kept short; extensive reviews on the structure and physiology of trans- ferrin and the transferrin receptor can be found elsewhere [1-3].

\section{Physiology of transferrin and transferrin receptor}

\subsection{Transferrin (Tf) and transferrin receptor (TfR)}

Transferrin (Tf) is an abundant serum component with the capacity to bind and transport iron. The main function of this $80-\mathrm{kDa}$ glycoprotein $[4,5]$ consists of providing cells with iron which they need in the process of DNA synthesis for the activity of ribonucleotide reductase, and for specialized functions (synthesis of hemoglobin in reticulocytes; iron transport to the fetus in syncytial trophoblasts). Iron is supplied to cells by attachment of iron-loaded Tf to its specific cell surface receptor followed by receptor-mediated endocytosis, a process that efficiently internalizes receptorbound transferrin into cells. The transferrin receptor, a dimeric transmembrane glycoprotein of 180 $\mathrm{kDa}[6,7]$, is present on the surface of most proliferating higher eukaryotic cells $[8,9]$. Erythroblasts express particularly elevated numbers of up to 800000 TfR per cell. Proliferating TfR-expres- 
sing tissues include bone marrow, intestinal epithelium, and epidermis, but expression is also found in a few non-proliferating tissues such as hepatocytes, tissue macrophages, pituitary cells, pancreas islet cells, or the endothelium of brain capillaries. Tumor cells frequently carry elevated numbers of TfR compared with the corresponding normal cells. In tumor-bearing patients reduced serum levels of $\mathrm{Tf}$ are often observed.

\subsection{Receptor-mediated endocytosis and the intracellular cycle}

Receptor-mediated endocytosis is a natural process which cells utilize for the uptake of protein or peptides such as low-density lipoprotein, asialoglycoproteins, epidermal growth factor, transferrin, insulin, and small vitamins such as folic acid. Many viruses also gain entry to cells via receptor-mediated endocytosis. The first steps in this process include binding of the ligand to specific cell-surface receptors, receptor clustering and internalization through coated vesicles into endosomal acidic compartments. The subsequent pathways are strongly dependent on the type of receptor/ligand pair; the low endosomal $\mathrm{pH}$ may or may not trigger dissociation of receptor and ligand, and sorting processes may lead to degradative lysosomal compartments.

The receptor-mediated endocytosis process of Tf differs from other ligand/receptor pairs in several respects. After internalization, iron-loaded Tf releases the iron at the low endosomal $\mathrm{pH}$, while apoTf (iron-free $\mathrm{Tf}$ ) remains bound to the receptor. The receptor-apoTf complex is sorted into exocytic vesicles back to the cell surface, where apoTf has ca. 30-fold lower affinity for the TfR at the extracellular $\mathrm{pH}$ and is released into the medium. Whether iron-loading is necessary for the uptake of Tf-conjugates, has not been tested. (With polyvalent $\mathrm{Tf}$ conjugates, such as described in Sect. 4.4, iron-loading is no strict requirement [our unpublished observation].) The entire Tf cycle [10-12] may take only 4-5 min (as shown in K562 cells with ca. $150000 \mathrm{TfR}$ per cell) with a mean transit time of about 10 min and avoids lysosomal compartments. The rapid recycling leads to very high turnover numbers on the order of
$2 \times 10^{4}$ Tf molecules internalized per minute per cell [13]. A second, minor pathway with a longer transit time has been identified as routing to the trans-Golgi and then back to the plasma membrane [14a]. It also should be kept in mind that modification of $\mathrm{Tf}$, crosslinking the receptor (e.g. by the use of antibodies or multivalent ligands [14b]) and/or lysosomotropic agents may strongly influence the intracellular fate of $\mathrm{Tf}$.

\section{Targeted delivery of drugs, proteins and toxins via the transferrin receptor}

\subsection{Tf and TfR conjugates for improved uptake into cells}

Many low-molecular-weight, pharmacologically active compounds are readily taken up into cells by passive diffusion processes through the cell membrane, whereas the uptake of charged molecules or larger compounds such as peptides, proteins, or nucleic acids is restricted. Moreover, for several therapeutic applications the specific targeting of a subset of cells is desired. A great deal of data accumulated during the last decade demonstrate that the TfR-mediated endocytosis pathway may be exploited to solve both tasks, namely enhanced intracellular uptake as well as targeted delivery of biologically active compounds. Low-molecular-weight drugs, protein toxins, or larger structures such as liposomes or minibeads have been linked to Tf or to antiTfR antibodies (see Table 1). The linkages were produced by a wide variety of chemical conjugation procedures or by the generation of chimeric antiTfR fusion proteins.

The targeting of drugs or toxins to tumor cells by specific antibodies has long been a topic of interest [15]. Using monoclonal antibodies generated by immunizations with neoplastic cells, Trowbridge and Omary [8] and Sutherland and colleagues [9] identified the transferrin receptor as a major cell surface protein in proliferating cells. Based on this discovery, Trowbridge and Domingo synthesized antiTfR antibody conjugates of the plant toxin ricin A or the bacterial diphtheria tox- 
Table 1

Targeted delivery of compounds conjugated to transferrin or to anti-TfR antibodies

\begin{tabular}{|c|c|c|c|c|c|c|}
\hline Compound & Conjugated to & Target cells & Application & Special focus & Ref. & Year \\
\hline \multirow[t]{5}{*}{ Adriamycin } & Tf & & in vitro & & 16 & 1984 \\
\hline & $\mathrm{Tf}$ & leukemia cells & patients & & 17 & 1990 \\
\hline & $\mathrm{Tf}$ & & in vitro & mechanism & 18,19 & 1992 \\
\hline & $\alpha \operatorname{TfR} 5 \mathrm{E} 9$ & & in vitro & acid-labile link & 20 & 1990 \\
\hline & $\alpha \operatorname{TfR} 5 \mathrm{E} 9$ & Daudi & in vivo (nude mice) & effect of linker & 21,22 & $1990 / 1$ \\
\hline Daunorubicin & $\mathrm{Tf}$ & SCCL NCI-H69 & & & 23 & 1991 \\
\hline \multirow[t]{3}{*}{ Methotrexate } & $\alpha \mathrm{TfR}$ & CEM & in vivo & & 24 & 1985 \\
\hline & $\alpha \mathrm{TfR}$ & CEM & in vitro & monensin & 25 & 1988 \\
\hline & $\alpha \operatorname{TfR}$ & & in vivo & blood-brain barrier & 26 & 1991 \\
\hline \multirow[t]{4}{*}{ Ricin A-chain } & $\alpha \mathrm{TfR} B 3 / 25$ & CEM, M21 & in vitro & nude mice & 27 & 1981 \\
\hline & & bone marrow & in vitro & & 28 & 1984 \\
\hline & hTf & CEM & in vitro & & 29 & 1984 \\
\hline & Tf or $\alpha \mathrm{TfR}$ & & in vitro & monensin & 30 & 1984 \\
\hline Whole ricin & $\alpha \mathrm{TfR}$ & brain tumor (GBM) & & & 31 & 1987 \\
\hline Ricin A & $\alpha \operatorname{TfR} 7 \mathrm{D} 3,454 \mathrm{~A} 12$ & mesothelioma & nude mice, i.p. & monensin & 32 & 1987 \\
\hline Ricin A & $\begin{array}{l}\alpha \text {-muTfR R17 217, } \\
\text { YE1/9.9 }\end{array}$ & P88D1 & $\begin{array}{l}\text { syngeneic tumor } \\
\text { i.p. }\end{array}$ & & 33 & 1987 \\
\hline Ricin A & Tf or $\alpha$ TfR & CEM & in vitro & monensin & 34 & 1987 \\
\hline Ricin A & hTf & glioma, Jurkat & & monensin & 35 & 1988 \\
\hline Ricin A & $\alpha \operatorname{TfR} 454 \mathrm{~A} 12$ & CEM, MCF-7 & & lysosomatropic agents & 36 & 1989 \\
\hline Whole ricin & $\alpha \operatorname{TfR}$ & CEM & intratumor & solid tumors & 37 & 1989 \\
\hline Ricin A & $\alpha \operatorname{TfR} 7 \mathrm{D} 3$ & glioma cells & in vitro & monensin & 38 & 1990 \\
\hline Ricin A & $\begin{array}{l}\text { Tf, OKT9, } \\
\text { OX26 } \alpha \text { TfR }\end{array}$ & $\begin{array}{l}\text { Jurkat, CEM, 9L, } \\
\text { Hu214 }\end{array}$ & in vitro & HSA-monensin conjugates & 39 & 1990 \\
\hline Ricin A & $\begin{array}{l}\alpha \text { TfR MEM75 } \\
120-2 \mathrm{~A} 3\end{array}$ & $\begin{array}{l}\text { HL60, KG1, U937, } \\
\text { K562 }\end{array}$ & in vitro & leukemia & 40 & 1991 \\
\hline Ricin A & Tf or $\alpha$ TfR R17 217 & hybridoma & in vitro & intracell. path. monensin & 41 & 1991 \\
\hline Ricin A & $\alpha$ TfR 7D3 R17 217 & $\begin{array}{l}\text { mesothelioma colon } \\
\text { carcinoma }\end{array}$ & in vivo & monensin/lipid emulsion & 42 & 1991 \\
\hline $\begin{array}{l}\text { Diphtheria } \\
\text { toxin (DT) }\end{array}$ & $\alpha \mathrm{TfR}$ & & in vitro & & 27 & 1981 \\
\hline DT A-chain & Tf & LMTK- & in vitro & & 43 & 1985 \\
\hline CRM 107 & $\mathrm{Tf}$ & Jurkat, K562, SNB75 & in vitro & cytosol translocation & 44 & 1988 \\
\hline DT & Tf & LMTK-variant & in vitro & Tf recycling & 45 & 1988 \\
\hline CRM 103, 9 & Tf & Jurkat & in vitro & acid-labile link & 46 & 1989 \\
\hline DT-A-chain & Tf & L-cell mutant & in vitro & resistance & 47 & 1991 \\
\hline $\begin{array}{l}\text { DT388- } \alpha \text { TfR } \\
\text { fusion }\end{array}$ & & $\begin{array}{l}\text { A431, KB, MCF7, } \\
\text { OVCAR3, HUT102 }\end{array}$ & & & 48 & 1991 \\
\hline \multirow{3}{*}{$\begin{array}{l}\text { Pseudomonas } \\
\text { exotoxin }\end{array}$} & $\alpha \operatorname{TfR} \mathrm{B} 3 / 25, \mathrm{HB} 21$ & KB, A431, HUT-102 & in vitro & adenovirus & 49 & 1983 \\
\hline & $x \operatorname{TfR}$ & KB, A431, OVCAR & in vitro & verapamil, diltiazem & $50,51,52$ & $1984 / 5$ \\
\hline & $\alpha \operatorname{TfR} H B 21$ & ovarian cancer & nude mice & & 53 & 1986 \\
\hline (Lys)PE40 & $\alpha \mathrm{TfR}$ & A431 & nude mice, i.p. & s.c. tumor & 54 & 1989 \\
\hline $\begin{array}{l}\text { PE40- } \alpha \text { TfR } \\
\text { fusion }\end{array}$ & & $\begin{array}{l}\text { A431, KB, MCF7, } \\
\text { OVCAR3, HUT102 }\end{array}$ & & & 48 & 1991 \\
\hline \multirow[t]{3}{*}{ Saporin-6 } & hTf & K562 & in vitro & & 55 & 1988 \\
\hline & $\mathrm{hTf}$ & $\begin{array}{l}\text { Jurkat, CEM, 9L, } \\
\text { Hu214 }\end{array}$ & & HSA-monensin conjugates & 39 & 1990 \\
\hline & $\alpha \operatorname{TfR}$ & leukemic cells & & & 56 & 1991 \\
\hline
\end{tabular}


Table 1 (Continued)

\begin{tabular}{|c|c|c|c|c|c|c|}
\hline Compound & Conjugated to & Target cells & Application & Special focus & Ref. & Year \\
\hline \multirow[t]{2}{*}{ Gelonin } & $\alpha \mathrm{TfR}$ & Namalwa & in vivo & & 57 & 1987 \\
\hline & $\operatorname{Tf}$ & HL60 & & resistance & 58 & 1992 \\
\hline \multirow{3}{*}{$\begin{array}{l}\text { Pokeweed } \\
\text { antiviral } \\
\text { protein }\end{array}$} & $\alpha \mathrm{TfR}$ & $\begin{array}{l}\text { HSB-2, CEM, } \\
\text { MOLT-3 }\end{array}$ & in vitro & chloroquine & 59 & 1984 \\
\hline & $\alpha$ TfR 5E9 & HSB-2 in vitro & in vivo & stability & 60 & 1985 \\
\hline & $\alpha \operatorname{TfR}$ & & & photoactivation & 61 & 1992 \\
\hline Barley toxin & $\alpha \operatorname{TfR}$ & & & & 62 & 1991 \\
\hline \multirow{2}{*}{$\begin{array}{l}\text { Neocarzino- } \\
\text { statin }\end{array}$} & $\mathrm{Tf}$ & K562 & in vitro & & 63 & 1985 \\
\hline & & & & & 64 & 1990 \\
\hline Abrin variant & $\mathrm{hTf}$ & $\begin{array}{l}\text { glioblastoma, } \\
\text { melanoma }\end{array}$ & in vitro & monensin & 65 & 1992 \\
\hline Cholera toxin & GM1 OS-Tf & & in vitro & chloroquine & 66 & 1992 \\
\hline \multirow[t]{2}{*}{ RNaseA } & $\alpha \mathrm{TfR}$ or $\mathrm{Tf}$ & K562 & in vitro & & 67 & 1991 \\
\hline & $\alpha \operatorname{TfR} 5 \mathrm{E}-9,454 \mathrm{~A} 12$ & $\mathrm{~K} 562, \mathrm{U} 251$ & in vivo, nude mice & & 68 & 1992 \\
\hline $\begin{array}{l}\text { Angiogenin- } \\
\text { xTfR fusion } \\
\text { protein }\end{array}$ & & $\mathrm{K} 562$ & in vitro & & 69 & 1992 \\
\hline $\begin{array}{l}\text { TNF- }-\alpha \mathrm{TfR} \\
\text { fusion protein }\end{array}$ & & $\mathrm{K} 562$ & in vitro & & 70 & 1991 \\
\hline \multirow[t]{2}{*}{ Minibeads } & $\mathrm{Tf}$ & $\begin{array}{l}\text { leukemic cells, } \\
\text { reticulocytes }\end{array}$ & & internalization & 71 & 1983 \\
\hline & Tf & L2C leukemia & & internalization & 72 & 1987 \\
\hline Polymer & Tf or $\alpha \mathrm{TfR}$ & skin fibroblasts & & & 73 & 1989 \\
\hline Liposomes & $\mathrm{Tf}$ & L2C leukemia & & internalization & 72 & 1987 \\
\hline+ methotrexate & $\alpha \operatorname{TfR}$ & T-cell leukemia & in vitro & & 74,75 & 1989 \\
\hline+ ara-cytosine & Tf & $\mathrm{CV}-1$ & in vitro & & 76 & 1990 \\
\hline
\end{tabular}

in A subunit [27]. These conjugates displayed effective killing of human tumor cells in vitro at concentrations up to 1000 -fold lower than using the antibody combined with the non-coupled toxin fragments alone. Tumor growth inhibition was also found in a melanoma in vivo model in nude mice; however, in these experiments unmodified antibody also mediated growth inhibition to a similar extent (see also antitumor activity of antiTfR antibodies described in Refs. 85-88). Moreover, in these early experiments, the path- way by which the TfR-bound toxins enter the cells was not characterized.

During studies aimed at the elucidation of the cellular uptake of iron, Takahashi and Tavassoli demonstrated that the iron uptake pathway can be subverted for the delivery of $345-\mathrm{nm}$ minibeads linked to Tf into cellular vesicles of leukemia cells or reticulocytes [71]. In the same year Pastan and colleagues described the delivery of Pseudomonas exotoxin antiTfR antibody conjugates into cellular endosomes [49]. Subsequent stu- 
dies have confirmed that the Tf delivery pathway is very flexible in accommodating transport of both small drugs [16-26], such as adriamycin, and structures [72-76] such as Tf-coated liposomes.

Investigations with TfR-binding toxin conjugates and other immunotoxins had shown that despite efficient and specific receptor-mediated endocytosis the cytotoxicities were variable and often too low to be of therapeutic interest. Often natural toxins consist of two polypeptide chains. The A-chain contains the activity that inhibits the protein synthesis of the target cell, and the B-chain contains functions that trigger uptake into cellular vesicles and translocation of the A-chain to the cytosol. In the construction of immunotoxins the B-chain often has been replaced by a ligand such as $\mathrm{Tf}$ or $\alpha \mathrm{TfR}$, resulting in enhanced target cell specificity but also loss of the mechanism for translocation to the cytosol. As a consequence, the limiting step in making immunotoxins available for their intracellular action seemed to be the transport of the toxin part from the vesicular compartment to its target.

Several strategies have been reported to enhance the delivery and potency of TfR-targeted toxin conjugates. Pastan and colleagues had shown evidence that adenovirus, after receptormediated endocytosis, escapes into the cytoplasm by disrupting the endosome, thereby liberating other substances contained in the same vesicle [77]. Consistent with the idea that this disruption process may release immunotoxins from internal vesicles, the toxicity of Pseudomonas exotoxin conjugated to antiTfR or EGF was enhanced by the presence of adenovirus by up to 300 -fold [49] or 10000 -fold [77]. The enhancing activity appeared to reside in the protein coat of the virus. Antibodies against adenoviral penton base blocked the enhancing activity without affecting virus uptake, suggesting that the penton base is important in endosomolysis [78].

A series of basic, proton-binding substances that influence intracellular routing of endocytosed materials also potentiate the action of immunotoxins, such as the lysosomotropic agents ammonium chloride [36], amines [79] and chloroquine $[59,66]$, in addition to some lipophilic carboxylic ionophores (monensin, nigericin), and calcium channel blockers (verapamil [50-52], diltiazem [52], nifedipine). In particular, monensin has been shown to strongly enhance the cytotoxicity of immunotoxins such as TfR-targeted ricin A or methotrexate as described by Raso and colleagues $[25,30,32,34,38,42]$ and other groups $[35,39,41,65]$. The mechanism of action of monensin in this process is not clear. Monensin catalyzes cation exchange across lipid bilayers. It has the capacity to transport protons across the endosomal membranes, thereby altering the $\mathrm{pH}$. However, the potentiating effect on the action of immunotoxins exists at relatively low concentrations of monensin that do not affect endosomal $\mathrm{pH}$, and it seems that mechanisms that alter intracellular trafficking are involved [41]. For example, monensin has been reported to cause accumulation of transferrin in perinuclear vesicular compartments, whereas chloroquine does not show this effect [14]. Another frequently made observation is that, depending on the toxin conjugate, the different lysosomotropic agents have differential effects. Ammonium chloride was found to enhance toxicity of immunotoxins such as an antiTfR-linked ricin A conjugate [36] whereas the cytotoxic activity of a Tfconjugated diphtheria toxin protein [43] was abolished by ammonium chloride. Presumably in the latter case the $\mathrm{pH}$-triggered translocation of the DT A-chain mediated by the B-chain had been blocked.

Further approaches in immunotoxin delivery benefit from the efficient natural process by which the B-chain specifically assists translocation of the A-chain. For this purpose antibody conjugates of toxins have been prepared containing a "blocked" B-chain with reduced cell-surface binding. Diphtheria toxin mutants and conjugates thereof have been described by Youle and coworkers [44,80]. CRM 107 has 10000 -fold lower toxicity and 8000 -fold lower binding activity relative to native DT; conjugation to $\mathrm{Tf}$ reconstituted full activity. Moreover, the Tf-conjugate, unlike native DT, was also highly toxic to murine cells. Pastan and co-workers [54] constructed the targetcell-specific immunotoxin antiTfR-LysPE40 by conjugation of antiTfR antibodies with recombinant $40-\mathrm{kDa}$ fragments of Pseudomonas exotoxin that lack its cell-binding domain. 
The mode of chemical conjugation in the preparation of immunotoxins creates additional complexities in the evaluation of biological effects. Different linkages containing reducible disulfide bonds, non-reducible linkages such as thioethers [36], or acid-sensitive linkages [46,81] have been found to possess different biological behaviour. Moreover chemical cross-linking procedure rarely are site-specific and often produce heterogeneous products, also containing multiple cross-links. Recent developments that present elegant alternatives to chemical conjugation are applications where the conjugate consists exclusively of protein or peptide components. The Pastan group has generated several recombinant immunotoxins containing the truncated toxins PE40 or DT388 linked to single-chain versions of the variable antibody domain directed at the IL-2 receptor $[82,83]$ or the TfR [48]. Comparison of chemical conjugates (antiTfR-LysPE40) with the corresponding fusion protein showed a 750 -fold higher activity of the recombinant fusion protein. Similar findings have been made by Youle and colleagues who described a recombinant cytotoxic antiTfRRNase fusion protein [69] which is 1000 -fold more active than the corresponding chemically linked RNase hybrids $[67,68]$. Instead of using conventional immunogenic bacterial or plant toxins, the investigators converted a human serum RNase, angiogenin, into an immunotoxin by generating a fusion gene of angiogenin with a humanized antiTfR antibody heavy chain; expression in chimeric cells that secrete the light chain of the same antibody results in the formation of the antibodyangiogenin fusion protein.

\subsection{Targeting to various cell types via the transferrin receptor}

The constitutive expression of TfR is found in proliferating tissues such as the bone marrow, epidermis and intestinal epithelium, and, to a lesser extent, in non-proliferating tissues such as hepatocytes or macrophages. The TfR levels in proliferating malignant cells have often been found to be far higher than in the corresponding normal cells. The increased receptor levels result from changes in both proliferation and differentiation: i.e., TfR numbers in transformed cells are far higher than in non-proliferating cells and may be more than twice as high as in the corresponding normal cells even when proliferating at the same rate [84]. As internalization rates and intracellular routing of TfR are similar to that which occurs in normal cells [84], an overall enhanced rate of $T f$ endocytosis is observed. For these reasons the TfR has been proposed as a target for cancer therapy [85]. Trowbridge and colleagues used monoclonal antiTf $R$ antibodies to inhibit cell growth in vitro [86 87b] and in vivo [27,88] in some tumor systems. Other groups have shown that Tf-gallium complexes [89], the active form of the chemotherapeutic drug gallium nitrate, or Tf-indium complexes [90] inhibit growth of leukemic cells. The TfR-mediated delivery of toxins (see above, Sect. $3.1)$ has proven to be particularly effective in specifically killing TfR-expressing tumor cells in vitro. In order to demonstrate a potential applicability for therapy, TfR-targeted immunotoxins have been tested in several animal model systems. A human ovarian cancer model, where the malignant cells grow intraperitoneally as ascites in nude mice, has been used by Pastan and colleagues. They demonstrated that antiTfR-PE conjugates injected intraperitoneally are able to kill the ovarian cancer cells in the peritoneal cavity and prolong the survival of mice to 100 days or longer [53]. However, extraperitoneal cancer cells were not affected by the immunotoxin. In similar models for human mesothelioma or colorectal carcinoma Griffin and Raso [32,42] tested the effect of ricin A-antiTfR immunotoxin in intraperitoneal tumor xenografts in nude mice. Co-administration of monensin/lipid emulsion was essential for the antitumor effect. Prolonged survival of mice with advanced macroscopic intraperitoneal tumors and cure in $40 \%$ of mice with microscopic intraperitoneal tumors was observed.

Immunotoxins containing anti-murine TfR antibodies have been applied in a syngeneic peritoneal lymphoid tumor model [33]. McIntyre and co-workers reported activity of an antiTfR-gelonin conjugate against Burkitt's lymphoma neografts in nude mice upon direct intratumoral administration into subcutaneous nodules, or intravenous administration at the time of intraperito- 
neal tumor inoculation [57]. Established solid CEM tumors have been shown to completely regress upon intratumoral injection of whole ricinantiTfR antibody conjugates [37]. Intraperitoneal administration of adriamycin-antiTfR antibody conjugates $[21,22]$ significantly inhibited the growth of subcutaneous solid B-lymphoma xenografts in nude mice. The use of $\mathrm{Tf}-$ adriamycin in a preliminary clinical study in acute leukemia patients has been reported [17]. A promising further application in vivo has been reported using the immunotoxin antiTfR-LysPE40, where intraperitoneal administration caused regression of subcutaneous A431 tumors [54].

Targeting via the TfR may also allow delivery of compounds into brain tissues where access is restricted by the blood/brain barrier. Jefferies and colleagues [91] discovered that after injection into the blood, monoclonal antibodies against the TfR labeled the endothelium of brain capillaries but not of other tissues. Further studies showed binding, endocytosis and transcytosis of iodine-labeled Tf by brain capillaries [92,93]. Only $20 \%$ of Tf was found to be recycled whereas approximately $50 \%$ was transcytosed into the brain parenchyma. The tight brain capillary wall is devoid of intercellular gaps or channels that exist in other endothelial layers, and delivery of hydrophilic compounds by processes such as passive diffusion is prevented. The presence of specific transport systems for transferrin, insulin [94], amino acids or glucose in the capillary endothelial cell layer therefore seems to be important for providing the brain with nutrients. Recently, several groups have started to use the special transport activity of brain capillaries for the delivery of drugs, peptides, or antisense oligonucleotides to the brain [for review, see Ref. 95]. In order to exploit the Tf transcytosis pathway, Friden and colleagues prepared a conjugate between the antiTfR antibody OX-26 and methotrexate $[26,96]$. The conjugates, when injected intravenously into rats, were targeted to the brain capillaries where after $30 \mathrm{~min}$ the drug had accumulated to levels ca. 50-fold higher than unconjugated drug. After a further 24 hours the majority of the drug was found in the brain parenchyma fraction which is consistent with a transcytosis event. Since major distribution to other tissues will also occur, the delivery of relatively toxic compounds to the brain using antiTfR antibodies seems not generally applicable.

Data like those reviewed in this article give accumulating evidence that $\mathrm{Tf}$ or antiTfR antibodies are attractive candidates for the delivery of drugs or toxin proteins that are cytotoxic at very low doses; for example, one to two ricin A molecules are able to kill a cell. However, it is not yet proven whether by the use of Tf or antiTfR antibodies a sufficiently high targeting specificity can be obtained that would be required to avoid systemic toxicity (e.g. in the liver and bone marrow). The approach also suffers from the fact that many of the conjugates are highly immunogenic. Humanization of toxin conjugates is one approach to overcome this drawback [69]. Alternative ways may include receptor-mediated delivery of genes that express toxins or other therapeutic proteins (see below) under the control of tissue- or tumorspecific promoter elements, for intracellular generation of these protein within the target cells, thus avoiding some of the immune system exposure and systemic toxicity.

\section{Transferrin-receptor-mediated gene transfer}

\subsection{Viral and non-viral gene transfer methods}

The delivery of nucleic acids and expression of the contained genes in eukaryotic cells is a topic of increasing interest in molecular and cellular biology as well as in medicine $[97,98]$. Recombinant viral vectors with high gene transfer efficiency such as retroviral $[99,100]$, vaccinia virus $[101,102]$, adenovirus $[103,104]$ and adenovirus-associated virus $[105,106]$ have been developed in which part of the viral genome has been replaced by a gene to be introduced into eukaryotic cells. These vectors, however, can be limited in their cell tropism, in the size of the gene to be introduced, in the compatibility of the introduced DNA with viral replication, and the toxicity to the cells (e.g. vaccinia virus).

During the last 30 years non-viral gene transfer methods have been elaborated using nucleic acids associated with basic proteins $[107,108]$, cationic 
polymers such as DEAE-dextran [109,110], polyornithine [111], polybrene [112], calcium phosphate precipitates [113-115], liposomes [116-118], cationic lipids $[119,120]$, lipopolyamines $[121,122]$, or electroporation $[123,124]$ and microinjection [125]. General reviews are given by Felgner [126] and Cotten and Wagner [181]. These gene transfer techniques, although still not reaching the efficiencies of viral vectors, have the advantage of being very flexible with regard to the type and size of nucleic acid to be transported. Most importantly, the provision of synthetic gene-transfer vehicles with components that mediate specific binding to cellular receptors, endocytosis, and delivery to the nucleus of the cell may lead to improved gene transfer systems with broad applicability. Recent developments (see below) have demonstrated that receptor-mediated endocytosis pathways can be adopted for the delivery of DNA into eukaryotic cells.

\subsection{Receptor-mediated endocytosis of transferrin- DNA complexes}

More than 10 years ago the first reports were published $[127,128]$ describing the concept of exploiting natural endocytosis pathways of protein ligands for the delivery of DNA macromolecules. At that time it was far from obvious that the cellular endocytosis process of rather small proteins may be subverted for the uptake of large (up to several hundred nanometers) DNA particles. Subsequent studies on the TfR-mediated endocytosis pathway showed that coupling of Tf to $350 \mathrm{~nm}$ or $50 \mathrm{~nm}$ latex minibeads [71,72] or to liposomes [72] does not affect the cellular uptake and biological activity of $\mathrm{Tf}$ in $\mathrm{L} 1210$ leukemia cells, rat reticulocytes, or leukemic $\mathrm{L}_{2} \mathrm{C}$ cells. Pastan and co-workers suggested the delivery of DNA to cells by covalent linkages to protein ligands such as $\alpha_{2^{-}}$ macroglobulin [127]. More recently, based on this idea, Tf-DNA conjugates were prepared [129] which were found to bind TfR on rabbit bone marrow cells. Alternative approaches use compositions containing DNA associated with the protein-ligand in non-covalent mode. Stavridis and colleagues presented two ways of generating noncovalent linkages. Firstly, they showed evidence that $\mathrm{Tf}$-coated liposomes containing labeled DNA [130] or DNA with the $\beta$ - $\delta$-globin gene associated with non-histone chromosomal proteins [131] were bound and partially internalized by rabbit erythroblasts after intravenous injection into rabbits. Similar liposomes coated with other ligands for cellular binding have been successfully used for gene delivery and expression by other groups $[132,133]$. In a second approach presented by the group of Stavridis, the interaction of DNA with histones was utilized and complexes of tritium-labeled rabbit liver DNA and transferrin crosslinked to calf thymus histones were prepared [128]. These complexes were preferentially transported onto erythroblasts and reticulocytes in animal experiments. However, no data have been published demonstrating the uptake and expression of a gene using this system.

In order to generate well-defined DNA-binding ligands for receptor-mediated gene transfer, Ariatti and colleagues [134] suggested using proteins (such as transferrin and asialoglycoprotein) modified with positively charged $N$-acylurea groups that enable electrostatic binding to DNA [135]. $N$-Acylurea-modified transferrin was shown to be internalized by HeLa cells [136]. Although there are no published data on gene transfer using $\mathrm{N}$ acylurea transferrin as ligand, successful gene transfer and expression of a CAT marker plasmid was demonstrated using insulin conjugated to $\mathrm{N}$ acylurea albumin with the insulin serving as cell binding ligand and the $N$-acylurea binding the DNA [137]. A related approach developed by $\mathrm{Wu}$ and colleagues employs conjugates of asialo-orosomucoid and high-molecular-weight cationic poly(L)lysine. Complexes of these DNA-binding conjugates with DNA plasmids encoding CAT marker genes or therapeutically relevant genes were shown to result in gene expression both in vitro in cultured HepG2 hepatoma cells $[138,139]$ and in vivo in the liver of rats or rabbits [140-144].

Using conjugates of human $\mathrm{Tf}$ or the avian homologue of $\mathrm{Tf}$, conalbumin, with the polycations protamine or polylysine acting as the DNAbinding moieties, Birnstiel and colleagues [145] found efficient transferrin-dependent receptormediated delivery and expression of luciferase marker genes (see Fig. 1) in avian HD3 and hu- 


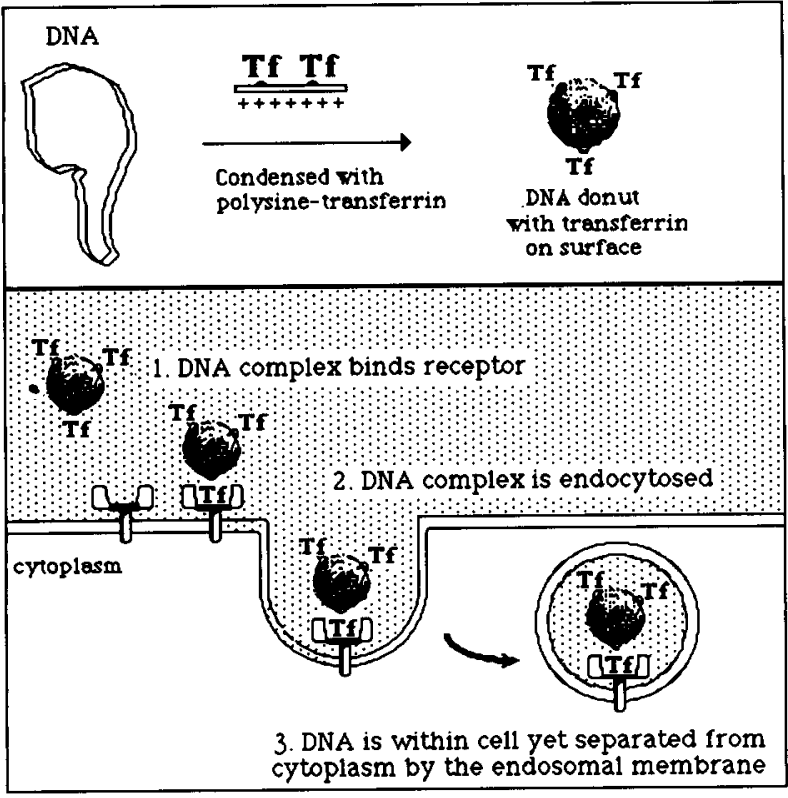

Fig. 1. Gene delivery to cells via the TfR-mediated endocytosis pathway.

man K562 erythroid cell cultures [146,147]. Conjugate synthesis involved the modification of transferrin and polycations with bifunctional reagents or, in a more specific manner, a ligation through the transferrin carbohydrate moiety [148]. Optimized delivery of DNA occurred with Tf-polycation to DNA ratios that resulted in electroneutrality. It was demonstrated that the presence of excess free transferrin interferes with DNA uptake [146] and that up-regulation of the transferrin receptor by agents like desferrioxamine increases the subsequent gene expression in K562 cells [147]. Using fluorescence-labeled DNA complexes, endocytosis into internal vesicles of more than $95 \%$ of the cells was found in the erythroid cells [146] and also a series of other cell lines [our unpublished results]. In many cell types the gene expression was strongly dependent on the presence of the lysosomatropic agent chloroquine during the transfection (see section below).

Initially the polycations were considered to be simply DNA-attachment elements. A novel type of transferrin conjugate was prepared that contains the DNA-intercalator ethidium homodimer instead of polylysine as the DNA-binding group
[148]. With these conjugates, however, the efficiencies of receptor-mediated gene delivery were considerably lower compared to the use of optimized Tf-polylysine-DNA complexes. Electron microscopy studies with the most efficient polylysine conjugates have shown that DNA, upon complex formation, is condensed to small toroid structures with a size of $80-100 \mathrm{~nm}$ [149]. The condensation of the DNA complexes by polylysine and other polycations strongly correlated with high gene transfer activity [149]. This led to the conclusion that packaging of DNA into particles of dimensions similar to the size of coated pits is important for efficient receptor-mediated endocytosis of the complex. Consistent with this hypothesis, the DNA delivery with $\mathrm{Tf}$-ethidium homodimer was drastically improved by condensation of the DNA with additional unmodified polylysine.

\subsection{Intracellular fate and expression of gene constructs in various cell types}

Although there is clear evidence regarding the first steps of DNA uptake (i.e. receptor binding and endocytosis into internal vesicles), subsequent steps by which the DNA is transported to the nucleus of the cell are still unclear. There is accumulating evidence that the majority of Tf-DNA complexes are not recycled to the cell surface but are delivered into lysosomal and other internal compartments, where they can be still detected more than 1 day after transfection [our unpublished results]. Nevertheless, in many cell lines, at least some of the DNA is transported to the nucleus, as expression of marker genes contained on up to 15-kb large DNA plasmids has been demonstrated [150]. LacZ gene transfer into K562 cells (in the presence of chloroquine) resulted in a particularly high expression of $\beta$-galactosidase between day 2 and day 9 post-transfection, showing that more than $90 \%$ of the cells expressed the gene. The Tfpolylysine method appeared to be particularly gentle, with no cytotoxic effects observed. Also $0.5-1 \%$ stable G418-resistant colonies were obtained upon transfection of K562 cells [150] and other cell lines such as the H9 T-cell line [Matt Cotten, unpublished results]. A series of TfR-bearing cells has been successfully transfected with $\mathrm{Tf}-$ 
polylysine-DNA complexes, but with significantly lower expression levels than in K562 or HD3 erythroid cells; these include [150] human HeLa, HepG2, H9, Ewing's sarcoma EW-2 cells, murine NIH 3T3 and hamster CHO cells, COS cells, chicken EGFR-myb transformed erythroblasts, REV-NPB4 lymphoblasts and normal bone marrow cells. The method also has been applied for gene transfer to respiratory epithelial cells [151]. Calabretta and colleagues have described the use of $\mathrm{Tf}$-polylysine for enhanced delivery of $c$-myb antisense oligonucleotides to HL-60 leukemic cells [152].

Similar receptor-mediated gene transfer systems have been developed using ligands other than transferrin: the viral protein HIV gp120; antibodies against CD4 or CD7 for the targeting of Tcells [150]; asialoglycoprotein [138-143] or synthetic galactose-containing peptides [153] for the targeting of hepatocytes via the asialoglycoprotein receptor; insulin [137, 154]; anti-thrombomodulin antibody [155-156] for lung targeting, lectins such as WGA [157] and additional ligands.

\section{Enhancement of delivery by endosome-disruptive viruses or peptides}

\subsection{Exit from endosomes as the limiting step of delivery}

Although Tf-polycation-DNA complexes provide satisfying levels of gene expression in several TfR-rich cell lines, in many other cell types the expression levels have been very low. Certainly there was no clear correlation between TfR levels and success of gene transfer; it became apparent that it was not receptor binding and uptake into endosomes, but later steps in the receptormediated gene delivery process that were limiting factors. In many cell types the reporter gene was expressed only in a small fraction (less than $1 \%$ ) of cells, although the DNA had been delivered into the vesicular system of most cells. The accumulation of the complexes in internal vesicles seemed to be a major block on the pathway and strategies had to be developed to prevent degradation of the DNA in lysosomal compartments and promote transport to the nucleus.

In the natural context, after endocytosis many non-recycling ligands are targeted to lysosomes and degraded by hydrolytic enzymes. A related process has been described for gene transfer by calcium phosphate precipitation, where over $50 \%$ of delivered DNA is found degraded in lysosomes [158]. A measure to block degradation of material in lysosomes involves the use of lysosomotropic agents such as chloroquine that might prevent acidification of lysosomes and accompanying activation of lysosomal hydrolytic enzymes. Including chloroquine during the first 4 hours of transfection enhances the expression levels in many gene transfer experiments mediated by $\mathrm{Tf}$-conjugates $[146,147]$ or other ligand-conjugates [153]. The action of chloroquine may be more complex. Other lysosomotropic substances that interfere with activation of lysosomal enzymes were found to be ineffective [150]. Surprisingly, monensin which promotes TfR-mediated toxin delivery (see Sect. 3.1) antagonizes the action of chloroquine in K562 cells. It also appears that incorporation of the metabolically stable poly(D)lysine, that might be predicted to protect delivered DNA, did not influence or improve gene transfer efficiency [149; our unpublished observations]. Based on these and further findings (see below), it was concluded that a major bottleneck of gene transfer is not the degradation but the release of DNA complexes from endosomes to the cytoplasm. The spectacular enhancement of gene transfer by chloroquine in $\mathrm{K} 562$ cells was then explained by a second mechanism of this agent [159]. In K562 cells the endosomes reach an unusually low $\mathrm{pH}$ due to a defect in $\mathrm{Na}^{+}, \mathrm{K}^{+}$-ATPase regulation [160]. Presumably, K562 endosomes accumulate exceptionally high amounts of the weak base chloroquine that may act osmotically [161], vacuolizing and destabilizing the endosomes. This also may explain the antagonistic effect of monensin, an ionophore that prevents the build-up of a $\mathrm{pH}$ gradient by a different, non-vacuolizing mechanism.

\subsection{Viral particles promote exit from endosomes}

The Tf-polylysine-DNA complexes share similarities with natural viruses both in size and in 
certain entry functions. Similar to viruses, which compact their nucleic acid genome with core proteins, the DNA is condensed with polylysine. The complexes are coated with $\mathrm{Tf}$ as a ligand for attachment to the cell and for receptor-mediated endocytosis, which resembles the entry process of viruses such as adenoviruses, influenza virus or the picornaviruses. The DNA complexes, however, still lack a further important function of viral entry: the release of the viral genome from endosomes into the cytoplasm. The normal endosomal acidification process specifically activates viral coat protein domains that trigger disruption of the endosomal membrane, in the case of membranefree viruses such as adenoviruses [77,78], or the fusion of the viral membrane with endosomal membranes in the case of enveloped viruses such as influenza virus [162].

In addition, the viral entry functions have been found to influence the intracellular delivery of other macromolecules [163-165]. Several groups observed that the presence of adenoviruses during receptor-mediated uptake of macromolecules such as Pseudomonas exotoxin conjugates targeted to the EGF receptor [77,78] or TfR [49] enhanced the entry of the macromolecules into the cell cytoplasm. The question was raised whether the endosome-disruption activity of adenoviruses might be used to enhance escape of the larger Tf-polylysine-DNA particles from vesicular compartments. It was found that the replication-defective adenovirus d1312 augmented the levels of Tf-mediated gene expression in a dose-dependent manner up to more than 2000 -fold in many cell lines that express high levels of both adenovirus and TfR, such as HeLa, KB or CFT1 cells [166]. Because only the endosome-disrupting activity of the virus protein capsid is thought to be required, it was possible to inactivate the viral genome by irradiation with short-wave UV or with long-wave UV plus psoralen without losing the enhancing activity on DNA gene transfer [167]. In contrast to recombinant adenoviral vectors, the DNA to be delivered is not part of the viral genome which allows flexibility in both size and sequence of the delivered DNA, demonstrated in examples such as the functional delivery of a $48-\mathrm{kb}$ luciferase-encoding cosmid [167].
For efficient gene delivery, co-localization of both adenovirus and Tf-polylysine-DNA complexes in the same endosome is essential. Enhancement of $\mathrm{Tf}$-mediated gene transfer, therefore, is only possible if relatively high levels of virus (up to more than 10000 particles/cell) are applied and if cells express sufficient levels of adenovirus (AdV) receptor. For instance, in K562 cells where in the presence of chloroquine Tf-mediated gene transfer worked very efficiently (see above) replacement of chloroquine by free adenovirus particles could not generate significant levels of gene expression. These drawbacks have been overcome by physically linking the adenovirus to the DNA complex [159 168169]. For this purpose replication-defective adenoviruses were provided with DNA-binding polylysine tails, either by direct covalent linkage through enzymatic coupling [159], by biochemical linkage between biotinylated viruses and streptavidin-polylysine [168], or by immunological linkage through adenoviral capsid-specific antibody polylysine conjugates [169].
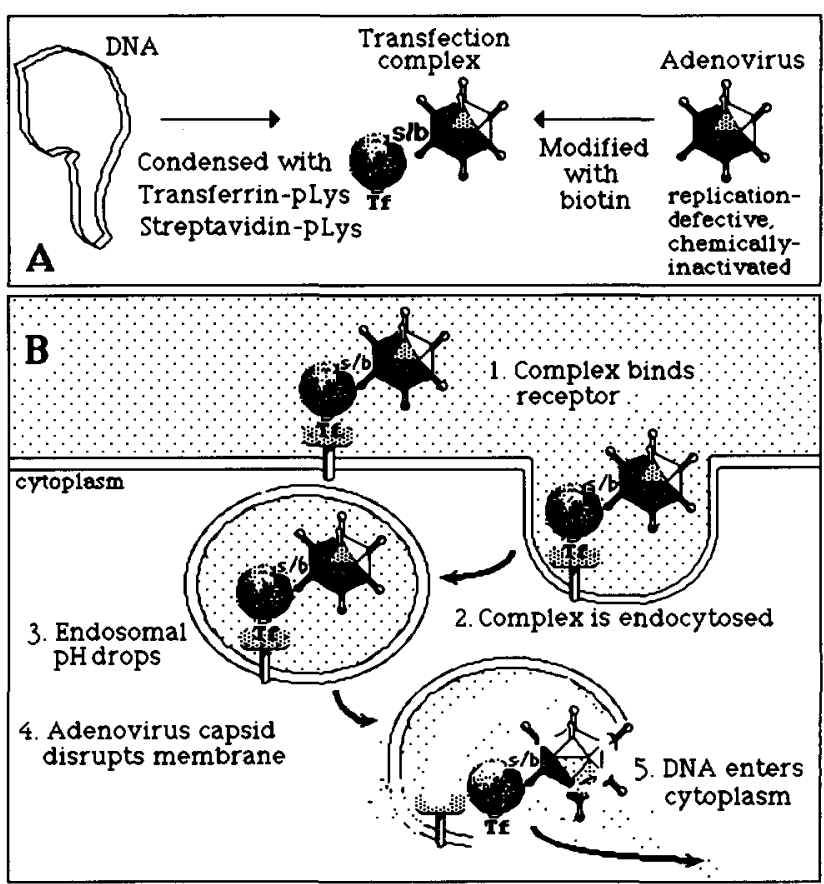

Fig. 2. Formation (A) and uptake of adenovirus-polylysine/ transferrin-polylysine/DNA combination complexes into cells (B). 
Table 2

TfR-mediated gene delivery

\begin{tabular}{|c|c|c|c|c|c|}
\hline \multirow[t]{2}{*}{ Cell type } & \multicolumn{5}{|c|}{ Transfection method } \\
\hline & TfpL & $\begin{array}{l}\text { TfpL + } \\
\text { chloroquine }\end{array}$ & $\begin{array}{l}\text { TfpL }+ \\
\text { free AdenoV }\end{array}$ & $\begin{array}{l}\text { TfpL }+ \\
\text { coupled AdenoV }\end{array}$ & $\begin{array}{l}\text { TfpL }+ \\
\text { Influ pLys }\end{array}$ \\
\hline \multicolumn{6}{|l|}{ Hepatocytes } \\
\hline Hep G2 & - & $+1-$ & +++ & & \\
\hline BNL.CI2 & - & $+1-$ & +++ & +++++ & +++ \\
\hline Primary & - & - & - & ++++ & \\
\hline \multicolumn{6}{|l|}{ Fibroblasts } \\
\hline $3 \mathrm{~T} 3$ & + & ++ & +++ & +++++ & ++ \\
\hline Mov-13 & $+1-$ & $+1-$ & & ++++ & + \\
\hline Mouse L-cells & $+1-$ & + & + & $+t+t$ & ++ \\
\hline Primary & & & & ++++ & + \\
\hline \multicolumn{6}{|l|}{ Myoblast/myotubes } \\
\hline $\mathrm{C} 2 \mathrm{C} 12$ & $+1-$ & & $+1-$ & +++++ & \\
\hline G8 & $+1-$ & & $+1-$ & +++++ & \\
\hline Primary & & & & +++ & \\
\hline \multicolumn{6}{|l|}{ Endothelial cells } \\
\hline Primary & & $+1-$ & + & +++ & $+1-$ \\
\hline \multicolumn{6}{|l|}{ Human neuroblastoma cell line } \\
\hline GI-ME-N & $+1-$ & $+1-$ & $+t+$ & $+++t$ & \\
\hline HeLa cells & + & + & +++++ & +++++ & +++ \\
\hline \multicolumn{6}{|l|}{ Melanoma } \\
\hline Mouse M-3 & & & & $+t+t+$ & +++ \\
\hline Human primary & - & $+1-$ & + & ++++ & ++ \\
\hline \multicolumn{6}{|l|}{ Mouse ES cell } \\
\hline CCE & $+1-$ & & + & ++ & \\
\hline Bruce 4 & $+1-$ & & ++ & ++ & + \\
\hline \multicolumn{6}{|l|}{ Erythroid cells } \\
\hline K562 & - & ++++ & + & +++++ & + \\
\hline Chicken HD3 & ++ & $+++t$ & +++ & +++++ & \\
\hline \multicolumn{6}{|l|}{ Bone marrow } \\
\hline Mouse & - & & - & ++ & \\
\hline Chicken & $+1-$ & & + & +++ & \\
\hline EBV-transformed human B-cells & - & - & - & +++ & + \\
\hline Mouse plasma cell lines (MPC11, SP2/0) & & + & ++ & +++ & \\
\hline
\end{tabular}

Luciferase activity: $+/-=1000-10000$ light units per $10^{6}$ cells; $+=10000-1$ million light units; $++=1-5$ million light units; $+++=5-50$ million light units; $++++=50-100$ million light units; $+++++=>100$ million light units.

$\mathrm{TfpL}=$ transferrin-polylysine; AdenoV $=$ replication-defective adenovirus $\mathrm{d} 1312 ;$ Influ/pLys $=$ influenza-peptide/polylysine.

The polycation modification of the virus allows ionic binding to the DNA which upon further addition of $\mathrm{Tf}$-polylysine is condensed to yield ternary complexes consisting of both Tf-DNA condensate and adenovirus. Theoretically, these combination complexes (see Fig. 2) may be internalized into cells via the TfR and/or the AdV receptor into the cell. Indeed, ternary complexes have been delivered to and expressed at very high levels in a broad variety of cell types and a large proportion of the target cells $(80 \%$ to almost $100 \%$ in cell lines such as K562 cells, HepG2 and BNL CL.2 hepatocyte lines or NIH 3T3 fibroblasts, and 20 $90 \%$ in primary cells such as fibroblasts, hepatocytes, myoblasts, epithelial and endothelial cells, or primary melanoma cells). A summary of transfection efficiencies obtained with the different methods of Tf-polylysine mediated gene transfer is given in Table 2. It has been shown that blocking of the $\mathrm{AdV}$ receptor by antibodies does not impair the activity in the gene transfer complex [170]. A further important attribute of the ternary 
DNA condensates resulting from the virus linkage has been the finding of effective gene expression after transfection with as few as ca. 1 viral particle and 100 DNA molecules per cell $[159,168]$. Also in this respect the system clearly stands out against conventional non-viral gene transfer methods (see Sect. 4.1) that require the input of several hundred thousand DNA molecules.

Searches for additional viruses that promote the release of Tf-DNA complexes from endosomes have led to the identification of alternatives to the human adenoviruses. As potential candidates, RNA viruses have been considered. Defective Moloney murine leukemia virus particles augment gene delivery to a modest extent but are limited by the low titers that can be obtained by this virus [M.C. and E.W., unpublished data]. This demonstrates that the endosome disruption activity is not a unique property of non-enveloped viruses, consistent with the cell permeabilization studies from Carrasco's group [164]. While neither the enveloped influenza virus particles nor purified influenza virus hemagglutinin were able to augment the gene transfer when incorporated in DNA complexes [171; our unpublished results], a human rhinovirus augmented the gene transfer up to 1000-fold [Dieter Blaas, Ernst Küchler and E.W., unpublished results].

A particularly effective alternative to the human AdV was found in the CELO virus, a chicken AdV. This virus displays both an endosomolytic and a gene transfer-enhancing activity similar to the human virus [157]. Because the chicken adenovirus is completely defective in mammalian cells, no cytopathic effects were observed even at high doses of virus that in the case of human E1Adefective adenovirus dl312 lead to toxic effects in several cell lines such as HeLa cells. The inactivity of the chicken virus genome allowed the generation of stably transfected cell clones at the high frequencies of $1-16 \%$ of transfected cells.

\subsection{Enhancement of gene transfer by membrane- disruptive peptides}

The gene transfer technique described above may become more attractive if virus-free versions can be generated in which the virus particles are replaced by endosome-disruptive proteins or synthetic compounds. The study of the membrane disruption and fusion processes that occur during viral entry and other biologically important membrane events has led to the identification of amphipathic $\alpha$-helical peptide sequences that are responsible for these membrane processes. The influenza virus hemagglutinin structure is particularly well-studied [162]. The $\mathrm{N}$-terminus of the subunit HA-2 contains a membrane-active peptide sequence which at neutral $\mathrm{pH}$, due to charge repulsions between negatively charged amino acid side-chain carboxylate groups, is prevented from adopting an $\alpha$-helical conformation. Upon lowering the $\mathrm{pH}$ to 5-6 (i.e. endosomal $\mathrm{pH}$ ) these charges are neutralized by protonation, allowing a transition to an $\alpha$-helical amphipathic structure which is able to interact and destabilize lipid membranes; in the natural context of influenza virus structure during entry, this is thought to facilitate the fusion of viral and endosomal membrane.

DNA complexes containing transferrin and polylysine have been linked to small synthetic peptides similar to the N-terminal sequence of hemagglutinin HA-2. In the context of the DNA complexes, these peptides have been found to disrupt membranes in a pH-dependent manner and substantially (100- to more than 1000-fold) augment Tf-mediated gene transfer in a series of cell lines $[172,173]$. Upon investigation of several related amphipathic peptides it was demonstrated that the peptide-containing complexes with highest, $\mathrm{pH}$-specific activity in liposome and erythrocyte membrane leakage assays also facilitated the most efficient gene transfer in cell culture experiments $[172,180]$. These synthetic gene-transfer vehicles (see Fig. 3) on the one hand still have 10- to $100-$ fold lower efficiency than adenovirus-linked DNA complexes; on the other hand, they have been found to be useful for the generation of stably transformed cell lines. Moreover, the synthetic gene transfer system represents an interesting model for the entry of a natural virus, in that the DNA complex contains both $\mathrm{Tf}$ as a ligand for endocytosis, and amphipathic peptides as $\mathrm{pH}$-specific endosome disrupting agents. 


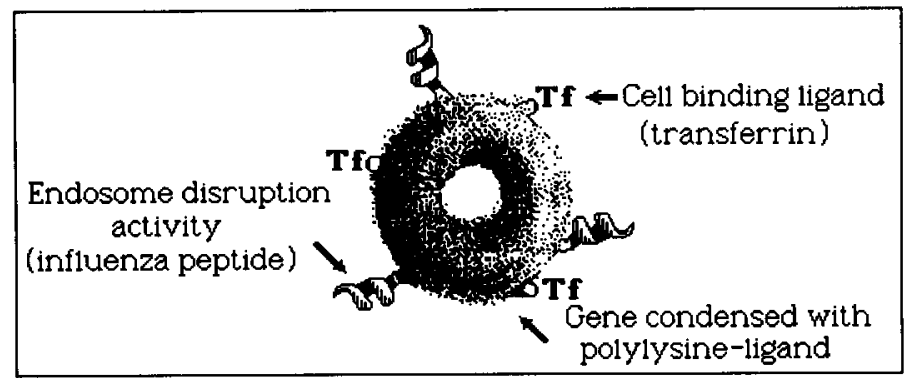

Fig. 3. Synthetic virus-like gene transfer system.

\section{Applications and limitations}

\subsection{Gene delivery ex vivo and in vivo}

The adenovirus-DNA combination complexes can efficiently deliver genes to a large proportion $(10-90 \%)$ of primary cells in culture such as endothelial cells [174], primary fibroblasts, hepatocytes, myoblasts and primary human melanoma cells. However, systemic application of the complexes by tail vein injection in mice or rats was largely unsuccessful due to inactivation of the complexes by blood components [E.W., M.C., and Kurt Zatloukal, unpublished observations] such as the complement system [175,176]. There was no significant gene expression in any organ, as the majority of complexes were found to be accumulated and presumably degraded by the reticuloendothelial system in liver and spleen. However, employing strategies that reduce the interaction of the complexes with blood (such as local injection into the liver of rats) produce significant luciferase reporter gene expression of $4 \times 10^{6}$ light units/injection site. By clamping off parts of the blood supply during the injection, the mixing of complexes with the blood was significantly slowed, and this improved gene transfer about 10fold over the standard injection. In tail veins of mice, as a model for in vivo gene transfer to endothelial cells of blood vessels, a similar gene expression was found after local administration with the blood supply clamped off for $20 \mathrm{~min}$ [Kurt Zatloukal, E.W., M.C., and Max Birnstiel, unpublished results]. Instillation of the complexes into the lung has resulted in gene transfer to the airway epithelium [177] - however, at levels that are significantly lower that those achieved with recombinant adenovirus vectors.

\subsection{Applications in gene and cancer therapy}

Although receptor-mediated gene transfer in vivo shows clear limitations, delivery into primary cells in culture is very efficient. The high efficiency of delivery to primary cells when the culture environment can be controlled will allow the use of this system for ex vivo treatment of cells harvested from a patient, followed by reimplantation in the patient. For example the clotting factor VIII, deficient in hemophilia A, can be produced by transfected primary fibroblasts at levels more than 10 fold higher than those generated by retroviral vectors [178]. This will facilitate the generation of factor VIII-expressing fibroblast implants for in situ expression of this protein. Other applications include factor VIII or dystrophin (for the correction of muscular dystrophy) expression in myoblasts that will be reimplanted into, and fused with, long-lived muscle tissue.

One exceptionally well-suited application of transferrin receptor-mediated gene delivery will be in the delivery of genes to tumor cells. Part of the success of this approach lies in the rapid proliferation state and therefore high levels of transferrin receptor cycling on tumor cells. One might consider using this system to deliver toxin genes directly into the tumor mass for elimination of these cells. However, the poor survival of our complexes in the bloodstream coupled with the requirement to introduce the gene into every cell in the tumor limits this application.

Recent advances in the understanding of tumor 


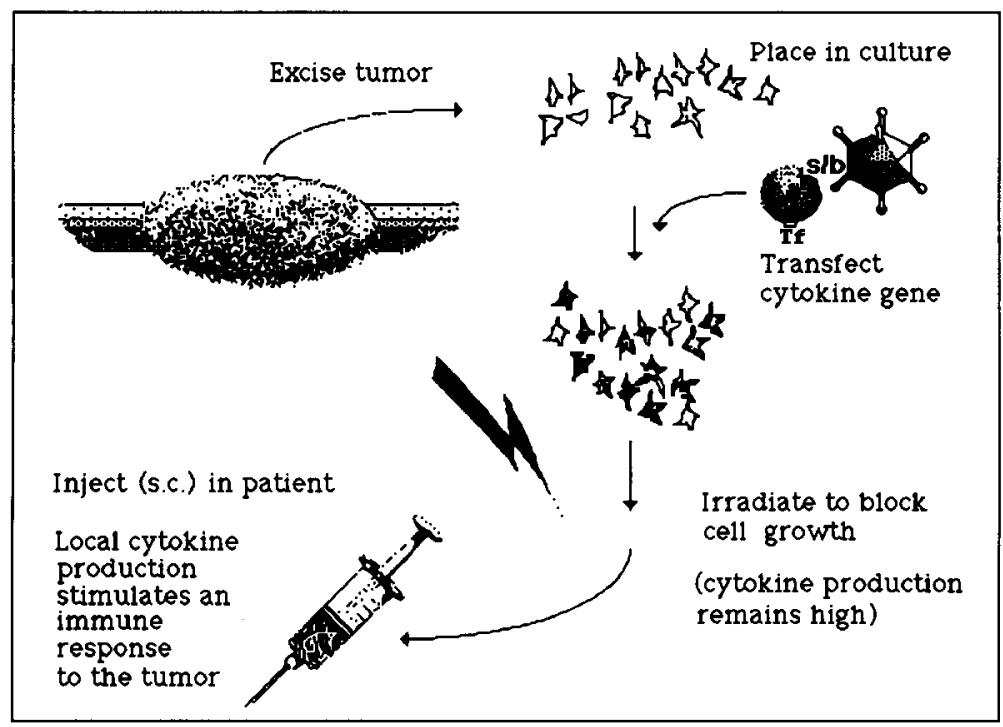

Fig. 4. Preparation of a tumor vaccine.

immunology have promoted the idea of a tumor vaccine. The concept is as follows (Fig. 4): after surgical removal of the tumor from patients with, for example, high-risk primary melanoma, a primary culture is transfected with one or several cytokine genes. X-ray irradiation blocks cell division and the tumor cells, which continue to live and produce cytokine, are applied as vaccine that is expected to induce a systemic immune response against unmodified residual tumor cells that otherwise lead to metastasis. This gene transfer technique seems to be particularly applicable for cytokine gene transfer into tumors because it has several advantages over established protocols, in that a high percentage of primary tumor cells can be targeted, leading to high-level gene expression without the need for selecting transfected clones. Murine M3 melanoma cells transfected with IL-2 or IFN- $\gamma$ gene constructs have been shown to produce high levels of cytokines [179]. In the corresponding mouse model the M-3 tumor cells have been injected into the flanks of syngeneic DBA-2 mice; the control tumor cells develop tumors in 6/ 6 animals within 2 weeks, whereas injection of M3 cells transfected with an IL-2 construct have lost their tumorigenicity.

\section{References}

[1] Huebers, H.A. and Finch, C.A. (1987) The physiology of transferrin and transferrin receptors, Physiol. Rev. 67, 520-581.

[2] Thorstensen, K. and Romslo, I. (1990) The role of transferrin in the mechanism of cellular iron uptake, Biochem. J. 271, 1-10.

[3] Taetle, R. (1990) The role of transferrin receptors in hemopoietic cell growth, Exp. Hematol. 18, 360-365.

[4] MacGillivray, R.T.A., Mendez, E., Shewale, J.G., Sinha, S.K., Lineback-Zins, J. and Brew, K. (1983) The primary structure of human serum transferrin, J. Biol. Chem. 258, 3543-3553.

[5] Bailey, S., Evans, R.W., Garratt, R.C., Gorinsky, B., Hasnain, S., Horsburgh, C., Jhoti, H., Lindley, P.F., Mydin, A., Sarra, R. and Watson, J.L. (1988) Molecular stiacture of serum transferrin at $3.3-\AA$ resolution, Biochemistry $27,5804-5812$.

[6] Schneider, C., Sutherland, R., Newman, R. and Greaves, M. (1982) Structural features of the cell surface receptor for transferrin that is recognized by the monoclonal antibody OKT9, J. Biol. Chem. 257, 8516 8522.

[7] Borhani, D.W. and Harrison, S.C. (1991) Crystallization and X-ray diffraction studies of a soluble form of the human transferrin receptor, J. Mol. Biol. 218, 685-689.

[8] Trowbridge, I.S. and Omary, M.B. (1981) Human cell surface glycoprotein related to cell proliferation is the receptor for transferrin, Proc. Natl. Acad. Sci. USA 78, 3039.

[9] Sutherland, R., Delia, D., Schneider, C., Newman, R., Kemshead, J. and Greaves, M. (1980) Ubiquitous cell- 
surface glycoprotein on tumor cells is proliferationassociated receptor for transferrin, Proc. Natl. Acad. Sci. USA 78, 4515-4519.

[10] Dautry-Varsat, A., Ciechanover, A. and Lodish, H.F. (1983) $\mathrm{pH}$ and the recycling of transferrin during receptor-mediated endocytosis, Proc. Natl. Acad. Sci. USA 80, 2258-2262.

[11] Klausner, R.D., Ashwell, G., van Renswoude, J., Harford, J.B. and Bridges, K.R. (1983) Binding of apotransferrin to K562 cells: explanation of the transferrin cycle, Proc. Natl. Acad. Sci. USA 80, 2263-2266.

[12] Bali, P.K., Zak, O. and Aisen, P. (1991) A new role for the transferrin receptor in the release of iron from transferrin, Biochemistry 30, 324-328.

[13] Ciechanover, A., Schwartz, A.L., Dantry-Varsat, A. and Lodish, H.F. (1983) Kinetics of internalization and recycling of transferrin and the transferrin receptor in a human hepatoma cell line, J. Biol. Chem. 258, 9681-9689.

[14a] Stein, B.S., Bensch, K.G. and Sussman, H.H. (1984) Complete inhibition of transferrin recycling by monensin in K562 cells, J. Biol. Chem. 259, 14762-14772.

[14b] Lesley, J., Schulte, R. and Woods, J. (1989) Modulation of transferrin receptor expression and function by antitransferrin receptor antibodies and antibody fragments, Exp. Cell Res. 182, 215-233.

[15] Gilliland, D.G., Steplewski, Z., Collier, R.J., Mitchell, K.F., Chang, T.H. and Koprowski, H. (1980) Antibodydirected cytotoxic agents: Use of monoclonal antibody to direct the action of toxin A chain to colorectal carcinoma cells, Proc. Natl. Acad. Sci. USA 77, 4539-4543.

[16] Yeh, C.J. and Faulk, W.P. (1984) Killing of human tumor cells in culture with adriamycin conjugates of human transferrin, Clin. Immunol. Immunopath. 32, 1-11.

[17] Faulk, W.P., Taylor, C.G., Yeh, C.J. and McIntyre, J.A. (1990) Preliminary clinical study of transferrin-adriamycin conjugate for drug delivery to acute leukemia patients, Mol. Biother. 2, 57-60.

[18] Barabas, K., Sizensky, J.A. and Faulk, W.P. (1992) Transferrin conjugates of adriamycin are cytotoxic without intercalating nuclear DNA, J. Biol. Chem. 267, 9437-9442.

[19] Sun, I.L., Sun, E.E., Crane, F.L., Morre, D.J. and Faulk, W.P. (1992) Inhibition of transplasma membrane electron transport by transferrin-adriamycin conjugates, Biochim. Biophys. Acta 1105, 84-88.

[20] Greenfield, R.S., Kaneko, T., Daues, A., Edson, M.A., Fitzgerald, K.A., Olech, L.J. and Braslawsky, G.R. (1990) Evaluation in vitro of adriamycin immunoconjugates synthesized using an acid-sensitive hydrazone linker, Cancer Res. 50, 6600-6607.

[21] Braslawsky, G.R., Edson, M., Pearce, W., Kaneko, T. and Greenfield, R.S. (1990) Antitumor activity of adriamycin (hydrazone-linked) immunoconjugates compared with free adriamycin and specificity of tumor cell killing, Cancer Res. 50, 6608-6614.

[22] Braslawsky, G.R., Kadow, K., Knipe, J., McGoff, K., Edson, M., Kaneko, T. and Greenfield, R.S. (1991)
Adriamycin(hydrazone)-antibody conjugates require internalization and intracellular acid hydrolysis for antitumor activity, Cancer Immunol. Immunother. 33, 367374.

[23] Bejaoui, N., Page, M. and Noel, C. (1991) Cytotoxicity of transferrin-daunorubicin conjugates, Anticancer Res. 11, $2211-2213$

[24] Kanellos, J., Pietersz, G.A. and McKenzie, I.F. (1985) Studies of methotrexate-monoclonal antibody conjugates for immunotherapy, J. Natl. Cancer Inst. 75, 319-332.

[25] Raso, V., Fehrmann, C., Solan, V.C. and Rosowsky, A. (1988) Monensin is obligatory for the cytotoxic action of a disulfide linked methotrexate-anti-transferrin receptor conjugate, Biochem. Biophys. Res. Commun. 150, 104 110.

[26] Friden, P.M., Walus, L., Musso, G.F., Taylor, M.A., Malfroy, B. and Starzyk, R.M. (1991) Antitransferrin receptor antibody and antibody-drug conjugates cross the blood-brain barrier, Proc. Natl. Acad. Sci. USA 88, 4771-4775

[27] Trowbridge, I.S. and Domingo, D. (1981) Anti-transferrin receptor monoclonal antibody and toxin-antibody conjugates affect growth of human tumor cells, Nature 294, 171-173.

[28] Lesley, J., Domingo, D.L., Schulte, R. and Trowbridge, I.S. (1984) Effect of an anti-murine transferrin receptorricin A conjugate on bone marrow stem and progenitor cells treated in vitro, Exp. Cell. Res. 150, 400.

[29] Raso, V. and Basala, M. (1984) A highly cytotoxic human transferrin-ricin A chain conjugate used to select receptor-modified cells, J. Biol. Chem. 259, 1143-1149.

[30] Raso, V. and Lawrence, J. (1984) Carboxylic ionophores enhance the cytotoxic potency of ligand- and antibodydelivered ricin A chain, J. Exp. Med. 160, 1234-1240.

[31] Zovickian, J., Johnson, V. and Youle, R. (1987) Potent and specific killing of human malignant brain tumor cells by an anti-transferrin receptor antibody-ricin immunotoxin, J. Neurosurg. 66, 850-861.

[32] Griffin, T.W., Richardson, C., Houston, L.L., LePage, D., Bogden, A. and Raso, V. (1987) Antitumor activity of intraperitoneal immunotoxins in a nude mouse model of human malignant mesothelioma, Cancer Res. 47, 42664270.

[33] Bjorn, M.J. and Groetsema, G. (1987) Immunotoxins to the murine transferrin receptor: intracavitary therapy of mice bearing syngeneic peritoneal tumors, Cancer Res. 47, 6639-6645.

[34] Raso, V., Watkins, S.C., Slayter, H. and Fehrmann, C. (1987) Intracellular pathway of ricin A chain cytotoxins, Ann. NY Acad. Sci. 507, 172-186.

[35] Colombatti, M., Bisconti, M., Dell'Arciprete, L., Gerosa, M.A. and Tridente, G. (1988) Sensitivity of human glioma cells to cytotoxic heteroconjugates, Int. J. Cancer 42, 441-448.

[36] Ramakrishnan, S., Bjorn, M.J. and Houston, L.L. (1989) Recombinant ricin A chain conjugated to monoclonal antibodies: improved tumor cell inhibition in the presence 
of lysosomatropic compounds, Cancer Res. 49, 613-617.

[37] Kanellos, J., McKenzie, I.F. and Peitersz, G.A. (1989) Intratumor therapy of solid tumours with ricin-antibody conjugates, Immunol. Cell. Biol. 67, 89-99.

[38] Recht, L.D., Griffin, T.W., Raso, V. and Salimi, A.R. (1990) Potent cytotoxicity of an antihuman transferrin receptor-ricin A chain immunotoxin on human glioma cells in vitro, Cancer Res. 50, 6696-6700.

[39] Colombatti, M., Dell'-Arciprete, L., Chignola, R. and Tridente, G. (1990) Carrier protein-monensin conjugates: enhancement of immunotoxin cytotoxicity and potential in tumor treatment, Cancer Res. 50, 1385-1391.

[40] Engert, A., Brown, A. and Thorpe, P. (1991) Resistance of myeloid leukemia cell lines to ricin A-chain immunotoxins, Leuk. Res. 15, 1079-1086.

[41] Kornfeld, S.B., Leonard, J.E., Mullen, M.D. and Taetle, R. (1991) Assessment of ligand effects in intracellular trafficking of ricin A chain using anti-ricin hybridomas, Cancer Res. 51, 1689-1693.

[42] Griffin, T. and Raso, V. (1991) Monensin in lipid emulsion for the potentiation of ricin A chain immunotoxins, Cancer Res. 51, 4316-4322.

[43] O'Keefe, D.O. and Draper, R.K. (1985) Characterization of a transferrin-diphtheria toxin conjugate, J. Biol. Chem. 260, 932-937.

[44] Johnson, V.G., Wilson, D., Greenfield, L. and Youle, R.J. (1988) The role of the diphtheria toxin receptor in cytosol translocation, J. Biol. Chem. 263, 1295-1300.

[45] O'Keefe, D.O. and Draper, R.K. (1988) Two pathways of transferrin recycling evident in a variant of mouse LMTK-cells, Somat. Cell. Mol. Genet. 14, 473-487.

[46] Neville, D.M. Jr., Srinivasachar, K., Stone, R. and Scharff, J. (1989) Enhancement of immunotoxin efficacy by acid-cleavable cross-linking agents utilizing diphtheria toxin and toxin mutants, J. Biol. Chem. 264, 1465314661.

[47] Laurie, S.M. and Robbins, A.R. (1991) A toxin-resistant mouse L-cell mutant defective in protein transport along the secretory pathway, J. Cell Physiol. 147, 215-223.

[48] Batra, J.K., Fitzgerald, D.J., Chaudhary, V.K. and Pastan, I. (1991) Single-chain immunotoxins directed at the human transferrin receptor containing Pseudomonas exotoxin A or diphtheria toxin: Anti-TFR(Fv)-PE40 and DT388-Anti-TFR(Fv), Mol. Cell. Biol. 11, 2200-2205.

[49] Fitzgerald, D.J.P., Trowbridge, I.S., Pastan, I. and Willingham, M.C. (1983) Enhancement of toxicity of an anti-transferrin receptor antibody Pseudomonas exotoxin conjugates by adenovirus, Proc. Natl. Acad. Sci. USA 80 , 41344138.

[50] Akiyama, S., Gottesman, M.M., Hanover, J.A., Fitzgerald, D.J., Willingham, M.C. and Pastan, 1. (1984) Verapamil enhances the toxicity of conjugates of epithermal growth factor with Pseudomonas exotoxin and antitransferrin receptor with Pseudomonas exotoxin, J. Cell. Physiol. 120, 271-279.

[51] Pirker, R., FitzGerald, D.J., Hamilton, T.C., Ozols, R.F., Willingham, M.C. and Pastan, I. (1985) Anti-transferrin receptor antibody linked to Pseudomonas exotoxin as a model immunotoxin in human ovarian carcinoma cell lines, Cancer Res. 45, 751-757.

[52] Akiyama, S., Seth, P., Pirker, R., FitzGerald, D., Gottesman, M.M. and Pastan, I. (1985) Potentiation of cytotoxic activity of immunotoxins on cultured human cells, Cancer Res. 45, 1005-1007.

[53] FitzGerald, D.J., Willingham, M.C. and Pastan, I. (1986) Antitumor effects of an immunotoxin made with Pseudomonas exotoxin in a nude mouse model of human ovarian cancer, Proc. Natl. Acad. Sci. USA 83, 66276630.

[54] Batra, J.K., Jinno, Y., Chaudhary, V.K., Kondo, T., Willingham, M.C., FitzGerald, D.J. and Pastan (1989) Antitumor activity in mice of an immunotoxin made with anti-transferrin receptor and a recombinant form of Pseudomonas exotoxin, Proc. Natl. Acad. Sci. USA 86, 8545-8549.

[55] Bergamaschi, G., Cazzola, M., Dezza, L., Savino, E., Consonni, E. and Lappi, D. (1988) Killing of K562 cells with conjugates between human transferrin and a ribosome-inactivating protein (SO-6), $\mathrm{Br}$. J. Haematol. 68, 379-384.

[56] Cazzola, M., Bergamaschi, G., Dezza, L., D'Uva, R., Ponchio, L., Rosti, V. and Ascari, E. (1991) Cytotoxic activity of an anti-transferrin receptor immunotoxin on normal and leukemic human hematopoietic progenitors, Cancer Res. 51, 536-541.

[57] Scott, J.F. Jr., Goldmacher, V.S., Lambert, J.M., Jackson, J.V. and McIntyre, G.D. (1987) An immunotoxin composed of a monoclonal antitransferrin receptor antibody potent in vitro and in vivo effects against human tumors, J. Natl. Cancer Inst. 79, 1163-1172.

[58] Ishiguro, K., Ho, P.T. and Sartorelli, A.C. (1992) Characterization of the defect in a variant of HL-60 promyelocytic leukemia cells with reduced transferrin receptor expression, Somat. Cell. Mol. Genet. 18, 45-63.

[59] Ramakrishnan, S. and Houston, L.L. (1984) Inhibition of human acute lymphoblastic leukemia cells by immunotoxins: potentiation by chloroquine, Science 223, 58-61.

[60] Ramakrishnan, S. and Houston, L.L. (1985) Immunological and biological stability of immunotoxins in vivo as studied by the clearance of disulfide-linked pokeweed antiviral protein-antibody conjugates from blood, Cancer Res. 45, 2031-2036.

[61] Goldmacher, V.S., Senter, P.D., Lambert, J.M. and Blatter, W.A. (1992) Photoactivation of toxin conjugates, Bioconjug. Chem. 3, 104-107.

[62] Ebert, R.F. and Spryn, L.A. (1990) Immunotoxin construction with a ribosome-inactivating protein from barley, Bioconjug. Chem. 1, 331-336.

[63] Kohgo, Y., Niitsu, Y., Nishisato, T., Urushizaki, Y., Kondo, H., Fukushima, M., Tsushima, N. and Urushizaki, I. (1985) Transferrin receptor of tumor cells potential tools for diagnosis and treatment of malignancies. In: G. Spik, J. Montreuil, R.R. Crichton and J. Mazurier (Eds.), Proteins of Iron Storage and Transport, 
Elsevier Science Publishers, Amsterdam, pp. 155-169.

[64] Kohgo, Y., Kondo, H., Kato, J., Sasaki, K., Tsushima, N., Nishisato, T., Hirayama, M., Fujikawa, K., Shintani, N., Mogi, Y. and Niitsu, Y. (1990) Kinetics of internalization and cytotoxicity of transferrin-neocarzinostatin conjugate in human leukemia cell line, K562, Jpn. J. Cancer Res. 81, 91-99.

[65] Hall, W.A., Godal, A., Juell, S. and Fodstad, O. (1992) In vitro efficacy of transferrin-toxin conjugates against glioblastoma multiforme, J. Neurosurg. 76, 838-844.

[66] Pacuszka, T. and Fishman, P.H. (1992) Intoxication of cultured cells by cholera toxin: evidence for different pathways when bound to ganglioside GM1 or neoganglioproteins, Biochemistry 26, 4773-4778.

[67] Rybak, S.M., Saxena, S.K., Ackerman, E.J. and Youle, R.J. (1991) Cytotoxic potential of ribonuclease and ribonuclease hybrid proteins, J. Biol. Chem. 266, 21202-21207.

[68] Newton, D.L., Ilercil, O., Laske, D.W., Oldfield, E., Rybak, S.M. and Youle, R.J. (1992) Cytotoxic ribonuclease chimeras. Targeted tumoricidal activity in vitro and in vivo, J. Biol. Chem. 267, 19572-19578.

[69] Rybak, S.M., Hoogenboom, H.R., Meade, H.M., Raus, J.C.M., Schwartz, D. and Youle, R. (1992) Humanization of immunotoxins, Proc. Natl. Acad. Sci. USA 89, 31653169.

[70] Hoogenboom, H.R., Raus, J.C. and Volckaert, G. (1991) Targeting of tumor necrosis factor to tumor cells: secretion by myeloma cells of a genetically engineered antibody-tumor necrosis factor hybrid molecule, Biochim. Biophys. Acta 1096, 345-354.

[71] Takahashi, K. and Tavassoli, M. (1983) Internalization of iron-transferrin complex by murine L 1210 leukemia cells and rat reticulocytes demonstrated by a minibead probe, J. Ultrastruct. Res. 82, 314-321.

[72] Vidal, M., Sainte-Marie, J., Philippot, J.R. and Bienvenue, A. (1987) The influence of coupling transferrin to liposomes or minibeads on its uptake and fate in leukemic L2C cells, FEBS Lett. 216, 159-163.

[73] Flanagan, P.A., Kopeckova, P., Kopecek, J. and Duncan, R. (1989) Evaluation of protein- $N$-(2-hydroxypropyl)methacrylamide copolymer conjugates as targetable drug carriers. 1. Binding, pinocytic uptake and intracellular distribution of transferrin and anti-transferrin receptor antibody conjugates, Biochim. Biophys. Acta 993, 83-91.

[74] Hege, K.M., Daleke, D.L., Waldmann, T.A. and Matthay, K. (1989) Comparison of antiTac and antitransferrin receptor-conjugated liposomes for specific drug delivery to adult T-cell leukemia, Blood 74, 2043 2052.

[75] Matthay, K.K., Abai, A.M., Cobb, S., Hong, K., Paphadjopoulos, D. and Straubinger, R.M. (1989) Role of ligand in antibody-directed endocytosis of liposomes by human T-leukemia cells, Cancer Res. 49, 48794886.

[76] Brown, P.M. and Silvius, J.R. (1990) Mechanisms of delivery of liposome-encapsulated cytosine arabinoside to
$\mathrm{CV}-1$ cells in vitro. Fluorescence-microscopic and cytotoxic studies, Biochim. Biophys. Acta 1023, 341-351.

[77] FitzGerald, D.J.P., Padmanabhan, R., Pastan, I. and Willingham, M.C. (1983) Adenovirus-induced release of epidermal growth factor and Pseudomonas toxin into the cytosol of KB cells during receptor-mediated endocytosis, Cell 32, 607-617.

[78] Seth, P., FitzGerald, D., Ginsberg, H., Willingham, M. and Pastan, I. (1984) Evidence that the penton base is involved in potentiation of toxicity of Pseudomonas exotoxin conjugated to epidermal growth factor, Mol. Cell. Biol. 4, 1528-1533.

[79] Casellas, P., Bourrie, B., Gros, P. and Jansen, F.K. (1984) Kinetics of cytotoxicity induced by immunotoxins: enhancement by lysosomatropic amines and carboxylic ionophores, J. Biol. Chem. 259, 9359-9364.

[80] Greenfield, L., Johnson, V.G. and Youle, R.J. (1987) Mutations in diphteria toxin separate binding from entry and amplify immunotoxin selectivity, Science 238, 536539.

[81] Wellhöner, H.H., Neville, D.M. Jr., Srinivasachar, K. and Erdmann, G. (1991) Uptake and concentration of bioactive macromolecules by K 562 cells via the transferrin cycle utilizing an acid-labile transferrin conjugate, $J$. Biol. Chem. 266, 4309-4314.

[82] Chaudhary, V.K., Queen, C., Junghans, R.P., Waldmann, T.A., FitzGerald, D.J. and Pastan, I. (1989) A recombinant immunotoxin consisting of two antibody variable domains fused to Pseudomonas exotoxin, Nature $339,394-397$.

[83] Chaudhary, V.K., Gallo, M.G., FitzGerald, D.J. and Pastan, I. (1990) A recombinant single-chain immunotoxin composed of antiTac variable regions and a truncated diphtheria toxin, Proc. Natl. Acad. Sci. USA 87, 9491-9494.

[84] Sorokin, L.M., Morgan, E.H. and Yeoh, G.C.T. (1989) Transformation-induced changes in transferrin and iron metabolism in myogenic cells, Cancer Res. 49, 1941-1947.

[85] Trowbridge, I.S. (1988) Transferrin receptor as a potential therapeutic agent, Prog. Allergy 45, 121-146.

[86] Trowbridge, I.S. and Lopez, F. (1982) Monoclonal antibody to transferrin receptor blocks transferrin binding and inhibits human tumor cell growth in vitro, Proc. Natl. Acad. Sci. USA 79, 1175-1179.

[87a] Taetle, R., Honeysett, J.M. and Trowbridge, I.S. (1983) Effects of anti-transferrin receptor antibodies on growth of normal and malignant myeloid cells, Int. J. Cancer 32 , 343-349.

[87b] Taetle, R. and Honeyset, J.M. (1987) Effects of monoclonal antitransferrin receptor antibodies on in vitro growth of human solid tumor cells, Cancer Res. 47, 2040-2044.

[88] Sauvage, C.A., Mendelsohn, J.C., Lesley, J.F. and Trowbridge, I.S. (1987) Effects of monoclonal antibodies that block transferrin receptor function on the in vivo growth of a syngeneic murine leukemia, Cancer Res. 47, 747-753. 
[89] Chitambar, C.R., Matthaeus, W.G., Antholine, W.E., Graff, K. and O'Brian, W.J. (1988) Inhibition of leukemic HL60 cell growth by transferrin-gallium: effects on ribonucleotide reductase and demonstration of drug synergy with hydroxyurea, Blood 72, 1930-1936.

[90] Moran, P.L. and Seligman, P.A. (1989) Effects of transferrin-indium on cellular proliferation of a human leukemia cell line, Cancer Res. 49, 4237-4241.

[91] Jefferies, W.A., Brandon, M.R., Hunt, S.V., Williams, A.F., Gatter, K.C. and Mason, D.Y. (1984) Transferrin receptor on endothelium of brain capillaries, Nature 312 , $162-163$.

[92] Fishman, J.B., Handrahan, J.V., Conner, J., Dickey, B.F. and Fine, R.E. (1985) Receptor-mediated transcytosis of transferrin across the blood-brain barrier, J. Cell. Biol. 101, 423 (abstract no. 1592).

[93] Fishman, J.B., Rubin, J.B., Handrahan, J.V., Connor, J.R. and Fine, R.E. (1987) Receptor-mediated transcytosis of transferrin across the blood-brain barrier, $\mathbf{J}$. Neurosci. Res. 18, 299-304.

[94] Duffy, K.R. and Pardridge, W.M. (1987) Blood-brain barrier transcytosis of insulin in developing rabbits, Brain Res. 420, 32-38.

[95] Pardrige, W.M. (1992) Recent developments in peptide drug delivery to the brain, Pharmacol. Toxicol. 71, 3-10.

[96] Friden, P.M., Walus, L., Taylor, M., Musso, G.F., Abelleira, S.A., Malfroy, B., Tehrani, F., Eckman, J.B., Morrow, A.R. and Starzyk, R.M. (1992) Drug delivery to the brain using an anti-transferrin receptor antibody, NIDA Res. Monogr. 120, 202-217.

[97] Miller, A.D. (1992) Human gene therapy comes of age, Nature 357, 455-460.

[98] Felgner, P.L. and Rhodes, G. (1991) Gene therapeutics, Nature 349, 351-352.

[99] Miller, A.D., Jolly, D.J., Friedmann, T. and Verma, I. (1983) A transmissable retrovirus expressing human hypoxanthine phosphoribosyltransferase (HPRT): Gene transfer into cells obtained from humans deficient in HPRT, Proc. Natl. Sci. USA 80, 4709-4713.

[100] Armentano, D., Yu, S., Kantoff, P., Anderson, W.F. and Gilboa, E. (1987) Effect of internal viral sequences on the utility of retroviral vectors, J. Virol. 61, 1647-1650.

[101] Perkus, M.E., Limbach, K. and Paoletti, E. (1989) Cloning and expression of foreign genes in vaccinia virus, using a host range selection system, J. Virol. 63, 3829-3836.

[102] Falkner, F.G., and Moss, B. (1988) Escherichia coli gpt gene provides dominant selection for vaccinia virus open reading frame expression vectors, J. Virol. 62, 1849-1854.

[103] Ballay, A., Levrero, M., Buendia, M., Tiollais, P. and Perricaudet, M. (1985) In vitro and in vivo synthesis of the hepatitis $B$ virus surface antigen and of the receptor for polymerized human serum albumin from recombinant human adenoviruses, EMBO J. 4, 3861-65.

[104] Berkner, K.L. (1988) Development of adenovirus vectors for the expression of heterologous genes, Biotechniques 6 , 616-629.
[105] Hermonat, P.L. and Muzyczka, N. (1984) Use of adenoassociated virus as a mammalian DNA cloning vector: Transduction of neomycin resistance into mammalian tissue culture cells, Proc. Natl. Acad. Sci. USA 81, 6466 6470 .

[106] Samulski, R.J., Chang, L.-S. and Shenk, T. (1989) Helper-free stocks of recombinant adeno-associated viruses: Normal integration does not require viral gene expression, J. Virol. 63, 3822-3828.

[107] Smull, C.E. and Ludwig, E.H. (1962) Enhancement of the plaque-forming capacity of poliovirus ribonucleic acid with basic proteins, J. Bacteriol. 84, 1035-1040.

[108] Böttger, M., Vogel, F., Platzer, M., Kiessling, U., Grade, K. and Strauss, M. (1988) Condensation of vector DNA by the chromosomal protein HMG1 results in efficient transfection, Biochim. Biophys. Acta 950, 221-228.

[109] McCutchan, J. and Pagano, J.S. (1968) Enhancement of the infectivity of simian virus 40 deoxyribonucleic acid with diethylaminoethyl-dextran, J. Natl. Cancer Inst. 41, 351-357.

[110] Luthman, H. and Magnusson, G. (1983) High efficiency polyoma DNA transfection of chloroquine treated cells, Nucleic Acids Res. 11, 1295-1300.

[111] Farber, F.E., Melnick, J.L. and Butch, J.S. (1975) Optimal conditions for uptake of exogenous DNA by Chinese hamster lung cells deficient in hypoxanthineguanine phosphoribosyltransferase, Biochim. Biophys. Acta 390, 298-311.

[112] Kawai, S. and Nishizawa, M. (1984) New procedure for DNA transfection with polycation and dimethylsulfoxide, Mol. Cell. Biol. 4, 1172-1174.

[113] Graham, F.L. and van der Eb, A.J. (1973) A new technique for the assay of infectivity of human adenovirus 5 DNA, Virology 52,.456 467.

[114] Loyter, A., Scangos, G.A. and Ruddle, F.H. (1982) Mechanisms of DNA uptake by mammalian cells: Fate of exogenously added DNA monitored by the use of fluorescent dyes, Proc. Natl. Acad. Sci. USA 79, 422-426.

[115] Chen, C.A. and Okayama, H. (1988) Calcium phosphatemediated gene transfer: a highly efficient transfection system for stably transforming cells with plasmid DNA, Biotechniques 6, 632-638.

[116] Straubinger, R.M. and Paphadjopoulos, D. (1983) Liposomes as carriers for intracellular delivery of nucleic acids, Methods Enzymol. 101, 512-527.

[117] Mannino, R.J. and Gould-Fogerite, S. (1988) Liposome mediated gene transfer, BioTechniques 6, 682-690.

[118] Nicolau, C., Legrand, A.T. and Grosse, E. (1987) Liposomes as carriers for in vivo gene transfer and expression, Methods Enzymol. 149, 157-176.

[119] Felgner, P.L., Gadek, T.R., Holm, M., Roman, R., Chan, H.W., Wenz, M., Northrop, J.P., Ringold, G.M. and Danielsen, M. (1987) Lipofection: A highly efficient, lipid-mediated DNA-transfection procedure, Proc. Natl. Acad. Sci. USA 84, 7413-7417.

[120] Rose, J.K., Buonocore, L. and Whitt, M.A. (1991) A new cationic liposome reagent mediating nearly quantitative 
transfection of animal cells, Biotechniques 10, 520-525.

[121] Behr, J.P., Demeneix, B., Loeffler, J.P. and Perez-Mutul, J. (1989) Efficient gene transfer into mammalian primary endocrine cells with lipopolyamine-coated DNA, Proc. Natl. Acad. Sci. USA 86, 6982-6986.

[122] Loeffler, J.-P. and Behr, J.-P. (1993) Gene transfer into primary and established mammalian cell lines with lipopolyamine-coated DNA, Methods Enzymol. 217, 599618.

[123] Andreason, G.L. and Evans, G.A. (1988) Introduction and expression of DNA molecules in eukaryotic cells by electroporation, Biotechniques 6, 650-660.

[124] Ohtani, K., Nakamura, M., Saito, S., Nagata, K., Sugamura, T. and Hinuma, Y. (1989) Electroporation: application to human lymphoid cell lines for stable introduction of a transactivator gene of human T-cell leukemia virus type I, Nucl. Acids Res. 17, 1589-1604.

[125] Graessmann, M. and Graessmann, A. (1983) Microinjection of tissue culture cells, Methods Enzymol. 101, 482 491.

[126] Felgner, P.L. (1990) Particulate systems and polymers for in vitro and in vivo delivery of polynucleotides, Adv. Drug Deliv. Rev. 5, 163-187.

[127] Cheng, S.Y., Merlino, G.T. and Pastan, I.H. (1983) A method for coupling of proteins to DNA: synthesis of $\alpha_{2}-$ macroglobulin-DNA conjugates, Nucleic Acids Res. 11, 659-669.

[128] Stavridis, J.C. and Psallidopoulos, M. (1982) Use of transferrin as a gene-carrier to the erythroid cells of the marrow, Cell. Mol. Biol. 28, 15-18.

[129] Weiler, S., Ariatti, M. and Hawtrey, A.O. (1988) The preparation of poly(dT)-5'-transferrin conjugates and hybridisation studies with poly(dA)-tailed linearised pBR322 plasmid DNA, Biochem. Pharmacol. 37, 24052410 .

[130] Stavridis, J.C., Deliconstantinos, G., Psallidopoulos, M.C., Armenakas, N.A., Hadjiminas, D.J. and Hadjiminas, J. (1986) Construction of transferrin-coated liposomes for in vivo transport of exogenous DNA to bone marrow erythroblasts in rabbits, Exp. Cell Res. 164, 568572.

[131] Stavridis, J.C., Psallidopoulos, M.C., Armenakas, N.A. and Hadjiminas, J. (1984) Expression of the human $\beta-\delta$ globin gene in rabbits, Cell. Mol. Biol. 30, 209-216.

[132] Wang, C.-Y. and Huang, L. (1987) pH-sensitive immunoliposomes mediate target-cell specific delivery and controlled expression of a foreign gene in mouse, Proc. Natl. Acad. Sci. USA 84, 7851-7855.

[133] Kaneda, Y., Iwai, K. and Uchida, T. (1989) Increased expression of DNA cointroduced with nuclear protein in adult rat liver, Science 243, 375-378.

[134] Huckett, B., Gordhan, H., Hawtrey, R., Moodley, N., Ariatti, M. and Hawtrey, A. (1986) Binding of DNA to albumin and transferrin modified by treatment with water-soluble carbodiimides, Biochem. Pharmacol. 35, 1249-1257.

[135] Ariatti, M. and Hawtrey, A.O. (1987) The binding of
DNA to water soluble carbodiimide modified proteins, Med. Hypotheses 24, 29-41.

[136] Hawtrey, R., Ariatti, M. and Hawtrey, A.O. (1988) Binding and internalization of carbodiimide-modified transferrin by HeLa cells, Med. Sci. Res. 16, 769-770.

[137] Huckett, B., Ariatti, M. and Hawtrey, A.O. (1990) Evidence for targeted gene transfer by receptor-mediated endocytosis: Stable expression following insulin-directed entry of neo into HepG2 cells, Biochem. Pharmacol. 40, 253-263.

[138] Wu, G.Y. and Wu, C.H. (1987) Receptor-mediated in vitro gene transformation by a soluble DNA carrier system, J. Biol. Chem. 262, 4429-4432.

[139] Wu, G.Y. and Wu, C.H. (1988) Evidence for targeted gene delivery to HepG2 hepatoma cells in vitro, Biochemistry 27, 887-892.

[140] Wu, G.Y. and Wu, C.H. (1988) Receptor-mediated gene delivery and expression in vivo, J. Biol. Chem. 263, 14621-14624.

[141] Wu, C., Wilson, J. and Wu, G. (1989) Targeting genes: delivery and persistent expression of a foreign gene driven by mammalian regulatory elements in vivo, J. Biol. Chem. 264, 16985-16987.

[142] Wu, G.Y., Wilson, J.M., Shalaby, F., Grossman, M., Shafritz, D.A. and Wu, C.H. (1991) Receptor-mediated gene delivery in vivo. Partial correction of genetic analbuminemia in Nagase rats, J. Biol. Chem. 266, 14338-14342.

[143] Wilson, J.M., Grossman, M., Cabrerea, J.A., Wu, C.H. and Wu, G.Y. (1992) A novel mechanism for achieving transgene persistence in vivo after somatic gene transfer into hepatocytes, J. Biol. Chem. 267, 11483-11489.

[144] Wilson, J.M., Grossman, M., Wu, C.H., Chowdhury, N.R., Wu, G.Y. and Chowdhury, J.R. (1992) Hepatocyte-directed gene transfer in vivo leads to transient improvement of hypercholesterolemia in low density lipoprotein receptor-deficient rabbits, J. Biol. Chem. 267, 963-967.

[145] Wagner, E., Zenke, M., Cotten, M., Beug, H. and Birnstiel, M.L. (1990). Transferrin-polycation conjugates as carriers for DNA uptake into cells, Proc. Natl. Acad. Sci. USA 87, 3410-3414.

[146] Zenke, M., Steinlein, P., Wagner, E., Cotten, M., Beug, H. and Birnstiel, M.L. (1990) Receptor-mediated endocytosis of transferrin polycation conjugates: An efficient way to introduce DNA into hematopoietic cells, Proc. Natl. Acad. Sci. USA 87, 3655-3659.

[147] Cotten, M., Laengle-Rouault, F., Kirlappos, H., Wagner, E., Mechtler, K., Zenke, M., Beug, H. and Birnstiel, M.L. (1990) Transferrin-polycation-mediated introduction of DNA into human leukemic cells: stimulation by agents that affect the survival of transfected DNA or modulate transferrin receptor levels, Proc. Natl. Acad. Sci. USA 87, 4033-4037.

[148] Wagner, E., Cotten, M., Mechtler, K., Kirlappos, H. and Birnstiel, M.L. (1991) DNA-binding transferrin conjugates as functional gene-delivery agents: synthesis by 
linkage of polylysine or ethidium homodimer to the transferrin carbohydrate moiety, Bioconjugate Chem. 2, 226-231.

[149] Wagner, E., Cotten, M., Foisner, R. and Birnstiel, M.L. (1991). Transferrin-polycation-DNA complexes: The effect of polycations on the structure of the complex and DNA delivery to cells, Proc. Natl. Acad. Sci. USA 88, 4255-4259:

[150] Cotten, M., Wagner, E., and Birnstiel, M.L. (1993) Receptor mediated transport of DNA into eukaryotic cells, Methods Enzymol. 217, 618-644.

[151] Curiel, D.T., Agarwal, S., Romer, N., Wagner, E., Cotten, M., Birnstiel, M.L. and Boucher, R.C. (1992) Gene transfer to respiratory epithelial cells via the receptor-mediated endocytosis pathway, Am. J. Respir. Cell Mol. Biol. 6, 247-252.

[152] Citro, G., Perrotti, D., Cucco, C., D’Agnano, I., Sacchi, A., Zupi, G. and Calabretta, B. (1992) Inhibition of leukemia cell proliferation by receptor-mediated uptake of c-myb antisense oligodeoxynucleotides, Proc. Natl. Acad. Sci. USA 89, 7031-7035.

[153] Plank, C., Zatloukal, K., Cotten, M., Mechtler, K. and Wagner, E. (1992) Gene transfer into hepatocytes using asialoglycoprotein receptor mediated endocytosis of DNA complexed with an artificial tetra-antennary galactose ligand, Bioconjug. Chem. 3, 533-539.

[154] Rosenkranz, A.A., Yachmenev, S.V., Jans, D.A., Serebryakova, N.V., Murav'ev, V.I., Peters, R. and Sobolev, A.S. (1992) Receptor-mediated endocytosis and nuclear transport of a transfecting DNA construct, Exp. Cell Res. 199, 323-329.

[155] Trubetskoy, V.S., Torchilin, V.P., Kennel, S. and Huang, L. (1992) Use of N-terminal modified poly(L-lysine)antibody conjugates as a carrier for targeted gene delivery in mouse lung endothelial cells, Bioconjug. Chem. 3, 323327.

[156] Trubetskoy, V.S., Torchilin, V.P., Kennel, S. and Huang, L. (1992) Cationic liposomes enhance targeted delivery and expression of exogenous DNA mediated by $\mathrm{N}$ terminal modified poly(L-lysine)-antibody conjugate in mouse lung endothelial cells, Biochim. Biophys. Acta $1131,311-313$.

[157] Cotten, M., Wagner, E., Zatloukal, K. and Birnstiel, M.L. (1993) Chicken adenovirus (CELO virus) particles augment receptor-mediated DNA delivery to mammalian cells and yield exceptional levels of stable transformants, J. Virol. 67, 3777-3785.

[158] Orrantia, E. and Chang, P.L. (1990) Intracellular distribution of DNA internalized through calcium phosphate precipitation, Exp. Cell. Res. 190, 170-174.

[159] Zatloukal, K., Wagner, E., Cotten, M., Phillips, S., Plank, C., Steinlein, P., Curiel, D. and Birnstiel, M.L. (1992). Transferrinfection: A highly efficient way to express gene constructs in eukariotic cells, Ann. NY Acad. Sci. 660, 136-153.

[160] Sipe, D.M., Jesurum, A. and Murphy, R.F. (1991) Absence of $\mathrm{Na}^{+}, \mathrm{K}^{+}$-ATPase regulation of endosomal acidification in K562 erythroleukemia cells, J. Biol. Chem. 266, 3469-3474.

[161] Corley Cain, C., Sipe, D.M. and Murphy, R.F. (1989) Regulation of endocytic $\mathrm{pH}$ by the $\mathrm{Na}^{+}, \mathrm{K}^{+}$-ATPase in living cells, Proc. Natl. Acad. Sci. USA 86, $544-548$.

[162] Wiley, D.C. and Skehel, J.J. (1987) The structure and function of the hemagglutinin membrane glycoprotein of influenza virus, Annu. Rev. Biochem. 56, 365-94.

[163] Fernandez-Puentes, C. and Carrasco, L. (1980) Viral infection permeabilizes mammalian cells to protein toxins, Cell 20, 769-775.

[164] Otero, M.J. and Carrasco, L. (1987) Proteins are cointernalized with virion particles during early infection, Virology 160, 75-80.

[165] Defer, C., Belin, M.-T., Caillet-Boudin, M.-L. and Boulanger, P. (1990) Human adenovirus host interactions: comparative study with members of subgroups B and C, J. Virol. 64, 3661-3673.

[166] Curiel, D.T., Agarwal, S., Wagner, E. and Cotten, M. (1991). Adenovirus enhancement of transferrin-polylysine-mediated gene delivery, Proc. Natl. Acad. Sci. USA $88,8850-8854$.

[167] Cotten, M., Wagner, E., Zatloukal, K., Phillips, S., Curiel, D.T. and Birnstiel, M.L. (1992) High-efficiency receptor-mediated delivery of small and large $(48 \mathrm{~kb})$ gene constructs using the endosome disruption activity of defective or chemically inactivated adenovirus particles, Proc. Natl. Acad. Sci. USA 89, 6094-6098.

[168] Wagner, E., Zatloukal, K., Cotten, M., Kirlappos, H., Mechtler, K., Curiel, D.T. and Birnstiel, M.L. (1992). Coupling of adenovirus to transferrin-polylysine/DNA complexes greatly enhances receptor-mediated gene delivery and expression of transfected genes, Proc. Natl. Acad. Sci. USA 89, 6099-6103.

[169] Curiel, D.T., Wagner, E., Cotten, M., Birnstiel, M.L., Agarwal, S., Li, C.-M., Loechel, S. and Hu, P.-C. (1992) High-efficiency gene transfer by adenovirus coupled to DNA-polylysine complexes, Hum. Gene Ther. 3, 147154.

[170] Michael, S.I., Huang, C.-h., Rømer, M.U., Wagner, E., Hu, P.-c. and Curiel, D.T. (1993) Binding-incompetent adenovirus facilitates molecular conjugate-mediated gene transfer by the receptor-mediated endocytosis pathway, $\mathbf{J}$. Biol. Chem. 268, 6866-6869.

[171] Curiel, D.T. (1993) Adenovirus facilitation of molecular conjugate-mediated gene transfer, Prog. Med. Virol. 40, $1-18$.

[172] Wagner, E., Plank, C., Zatloukal, K., Cotten, M. and Birnstiel, M.L. (1992) Influenza virus hemagglutinin HA$2 \mathrm{~N}$-terminal fusogenic peptides augment gene transfer by transferrin-polylysine/DNA complexes: Towards a synthetic virus-like gene transfer vehicle, Proc. Natl. Acad. Sci. USA 89, 7934-7938.

[173] Plank, C., Zatloukal, K., Cotten, M., Mechtler, K. and Wagner, E. (1992) Gene transfer into hepatocytes using asialoglycoprotein receptor mediated endocytosis of DNA complexed with an artificial tetra-antennary 
galactose ligand, Bioconjug. Chem. 3, 533-539.

[174] Edgell, C.J.S., Hu, P.-c., Wagner, E. and Curiel, D.T. (1994) Gene transfer to endothelial cells using adenovirus polylysine--DNA complexes, Thromb. Haemost., submitted.

[175] Rent, R., Ertel, N., Eisenstein, R. and Gewurz, H. (1975) Complement activation by interaction of polyanions and polycations, J. Immunol. 114, 120-124.

[176] Chonn, A., Cullis, P.R. and Devine, D.V. (1991) The role of surface charge in the activation of the classical and alternative pathways of complement by liposomes, J. Immunol. 146, 42344241.

[177] Gao, L., Wagner, E., Cotten, M., Agarwal, S., Harris, C., Rømer, M., Miller, L., Hu, P-c. and Curiel, D. (1993) Direct in vivo gene transfer to the airway epithelium employing adenovirus-polylysine-DNA complexes,
Hum. Gene Ther. 4, 17-24.

[178] Zatloukal, K., Cotten, M., Berger, M., Schmidt, W., Wagner, E. and Birnstiel, M.L. (1993) Expression of human factor VIII by receptor-mediated, adenovirusaugmented gene delivery, Proc. Natl. Acad. Sci. USA, in press.

[179] Zatloukal, K., Schmidt, W., Cotten, M., Wagner, E., Stingl, G. and Birnstiel, M.L. (1993) Somatic gene therapy for cancer: the utility of transferrinfection in generating 'tumor vaccines', Gene 135, 199-207.

[180] Plank, C., Oberhauser, B., Mechtler, K., Koch, C. and Wagner, E. (1994) The influence of endosome-disruptive peptides on gene transfer using synthetic virus-like gene transfer systems, J. Biol. Chem. 269, in press (May issue).

[181] Cotten, M. and Wagner, E. (1993) Non-viral approaches to gene therapy, Curr. Opin. Biotechnol. 4, 705-710. 